\title{
Removal of Barium from Solution by Natural and Iron(III) Oxide-Modified Allophane, Beidellite and Zeolite Adsorbents
}

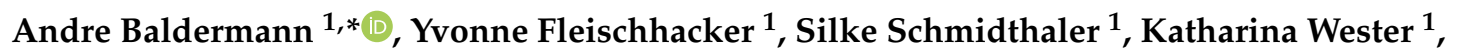 \\ Manfred Nachtnebel ${ }^{2}$ and Stefanie Eichinger ${ }^{1}$ \\ 1 Institute of Applied Geosciences \& NAWI Graz Geocenter, Graz University of Technology, \\ Rechbauerstraße 12, 8010 Graz, Austria; y.fleischhacker@stud.uni-graz.at (Y.F.); \\ silke.schmidthaler@gmx.at (S.S.); katharina.wester@gmx.at (K.W.); stefanie.eichinger@tugraz.at (S.E.) \\ 2 Institute of Electron Microscopy and Nanoanalysis, Graz Centre for Electron Microscopy (FELMI-ZFE), \\ Steyrergasse 17, 8010 Graz, Austria; manfred.nachtnebel@felmi-zfe.at \\ * Correspondence: baldermann@tugraz.at; Tel.: +43-(0)316-873-6850
}

Received: 11 May 2020; Accepted: 3 June 2020; Published: 5 June 2020

\begin{abstract}
Efficient capture of barium (Ba) from solution is a serious task in environmental protection and remediation. Herein, the capacity and the mechanism of Ba adsorption by natural and iron(III) oxide (FeO) modified allophane (ALO), beidellite (BEI) and zeolite (ZEO) were investigated by considering the effects of contact time, temperature, $\mathrm{pH}, \mathrm{Ba}^{2+}$ concentration, adsorbent dosage, the presence of competitive ions and adsorption-desorption cycles (regenerability). Physicochemical and mineralogical properties of the adsorbents were characterized by XRD, FTIR, SEM with EDX and $\mathrm{N}_{2}$ physisorption techniques. The $\mathrm{Ba}^{2+}$ adsorption fitted to a pseudo-first-order reaction kinetics, where equilibrium conditions were reached within $<30 \mathrm{~min}$. BEI, ALO and ZEO with(out) FeO-modification yielded removal efficiencies for $\mathrm{Ba}^{2+}$ of up to $99.9 \%, 97 \%$ and $22 \%$ at optimum $\mathrm{pH}$ ( $\mathrm{pH}$ 7.5-8.0). Adsorption isotherms fitted to the Langmuir model, which revealed the highest adsorption capacities for BEI and FeO-BEI ( $44.8 \mathrm{mg} / \mathrm{g}$ and $38.6 \mathrm{mg} / \mathrm{g}$ at $313 \mathrm{~K})$. Preferential ion uptake followed in the order: $\mathrm{Ba}^{2+}>\mathrm{K}^{+}>\mathrm{Ca}^{2+}>>\mathrm{Mg}^{2+}$ for all adsorbents; however, BEI and FeO-BEI showed the highest selectivity for $\mathrm{Ba}^{2+}$ among all materials tested. Barium removal from solution was governed by physical adsorption besides ion exchange, intercalation, surface complexation and precipitation, depending mainly on the absorbent type and operational conditions. BEI and FeO-BEI showed a high regenerability ( $>70-80 \%$ desorption efficiency after 5 cycles) and could be considered as efficient sorbent materials for wastewater clean-up.
\end{abstract}

Keywords: barium; adsorption; environment; wastewater treatment; surface modification

\section{Introduction}

The accumulation and overconcentration of hazardous metal ions in the aquatic and terrestrial environments of the Earth is a major threat for the ecological system and for human health, as most metal ions are non-biodegradable and tend to cumulate in living organisms, causing diseases and disorders [1-4]. In the last decades, intense research has been carried out to find advanced and economically attractive solutions, either for the complete elimination of critical metal ions from wastewater or for a concentration reduction below permissible limits set by the local and international standards [5,6]. Currently available wastewater treatment technologies include, for example, chemical precipitation, flocculation, coagulation, electrochemical methods, reverse osmosis, membrane separation and adsorption $[7,8]$. However, these methods greatly vary in effectiveness and operational costs; thus there is still a high demand for the development of new, 
efficient, green and low cost adsorbent materials [9-11]. Silicate based adsorbents, such as clay minerals and zeolites, can be advantageous over non-siliceous materials or composite materials, because they provide a plenty of adsorption sites due to the very small particle size, high surface area, porous structure and presence of surface functional groups and exchangeable sites, rendering these components ideal for wastewater treatment [12-15].

Recently, zeolites have received great attention for the remediation of solutions contaminated by critical metal ions $\left(\mathrm{Cd}^{2+}, \mathrm{Cr}^{3+}, \mathrm{Cs}^{+}, \mathrm{Co}^{2+}, \mathrm{Pb}^{2+}, \mathrm{Zn}^{2+}\right.$, etc. $)$ and for radioactive waste treatment due to their worldwide abundance, high thermal and radiation stability and uniform three-dimensional pore structure [5]. The short-range-order aluminosilicate phase allophane also exhibits good sorption capacities for certain metal ions, such as $\mathrm{Cs}^{+}, \mathrm{Ba}^{2+}, \mathrm{Co}^{2+}, \mathrm{Cu}^{2+}, \mathrm{Sr}^{2+}$ and $\mathrm{Zn}^{2+}$, owning to its unique physicochemical and surface (charge) properties, amphoteric ligand capacity and hollow "nanoball" structure [13,16-18]. Smectite group minerals, such as beidellite and montmorillonite, are also in use as adsorbents, ion exchangers and catalysts due to their low cost, high reactivity and worldwide distribution $[15,19,20]$.

Barium $\left(\mathrm{Ba}^{2+}\right)$ can occur in elevated concentrations in different soils, sediments, hydrocarbon deposits, river water and seawater as well as in wastewater of several industries, the military and agriculture [21,22]. The soluble Ba species are highly toxic and, if present in drinking water, may cause severe health problems (e.g., breathing difficulties, increased blood pressure and heart rhythm changes) even in low concentrations $[23,24]$. High concentrations of $\mathrm{Ba}^{2+}$ in drinking water have been associated with partly severe cases of multiple sclerosis and neurodegenerative diseases. Thus, the US Environmental Protection Agency has set the maximum concentration limit for $\mathrm{Ba}^{2+}$ in drinking water to $2 \mathrm{mg} / \mathrm{L}$ [20]. Apart from that, radioactive Ba (i.e., the isotope ${ }^{133} \mathrm{Ba}$ ) is one of the most common and most toxic radionuclides present in radioactive liquid waste $[25,26]$. It has a long half-life and high fission yield [5]. Thus, there is a strong need to separate $\mathrm{Ba}^{2+}$ ions from contaminated solutions, but detailed experimental studies on this topic are still scarce.

In this study, the adsorption of aqueous $\mathrm{Ba}^{2+}$ by natural and iron oxide modified allophane, beidellite and zeolite was investigated, representing highly promising (efficient, green and low-cost) adsorbents. The effects of contact time, solution $\mathrm{pH}$, temperature, adsorbent dosage, the presence of competing cations, initial $\mathrm{Ba}^{2+}$ concentration and the regenerability of the adsorbents were tested. The equilibrium adsorption data were fitted to both the Langmuir and Dubinin-Radushkevich isotherm models. Removal efficiencies and sorption capacities of $\mathrm{Ba}^{2+}$ by the novel materials are compared with other available adsorbent materials.

\section{Materials, Experimental and Methods}

\subsection{Raw Materials}

Allophane-rich soil material (ALO) from the allophane facies of the Santo Domingo de los Colorados deposit (Ecuador), bentonite rich in beidellite (BEI) from the "Johanneszeche" talc deposit near Göpfersgrün (Germany) and zeolite (ZEO: white natrolite intergrown with pale pink stilbite) from Pune (India) were used for the adsorption studies, because of their low cost, high abundance and sufficient sorption capacities. ALO and BEI were used as received without further grinding or purification. ZEO was gently crushed in a ball mill for $15 \mathrm{~min}$, following collection of the $<32 \mu \mathrm{m}$ size fraction by wet-sieving to obtain a similar grain size fraction as for the other adsorbents. The total organic carbon content of the raw materials is $\leq 0.5 \mathrm{wt} \%$; thus the effect of organic matter on the adsorption may be negligible.

\subsection{Iron(III) Oxide Modification Experiments}

Previous investigations have shown that iron(III) oxide-coated materials can exhibit adsorption properties better than the raw materials $[27,28]$. In order to prepare iron(III) oxide-coated adsorbents (Figure 1), a stock solution $(3.0 \mathrm{~L})$ containing $100 \mathrm{mg} / \mathrm{L}$ of $\mathrm{Fe}^{2+}$ was prepared by the dissolution of iron 
(II) chloride hydrate $\left(\mathrm{FeCl}_{2} \cdot \mathrm{H}_{2} \mathrm{O} ; \geq 98 \%\right.$, from Roth) in ultrapure water (Milli-Q Plus UV, Millipore, Merck, Darmstadt, Germany, $18.2 \mathrm{M} \Omega$ at $\left.25^{\circ} \mathrm{C}\right)$. A fraction $(5 \mathrm{~g})$ of the raw materials was transferred into $1.0 \mathrm{~L}$ of the freshly prepared $\mathrm{Fe}^{2+}$ stock solution. The $\mathrm{pH}$ of the suspension was adjusted to 8.0 by the addition of droplets of a $0.1 \mathrm{M} \mathrm{NaOH}$ solution. This induced the precipitation of iron (III) oxides, such as goethite $(\mathrm{FeOOH})$ and hematite $\left(\mathrm{Fe}_{2} \mathrm{O}_{3}\right)$. The suspension was aged under oxidizing conditions for $24 \mathrm{~h}$ at $298 \mathrm{~K}$. Vigorous stirring of the suspension at $350 \mathrm{rpm}$ ensured a homogenous distribution of the iron (III) oxides at the absorbents surface and a high precipitation quota of the iron (III) oxides. At the end of the experiments, $>90 \%$ of Fe by weight was removed from the solutions, as determined by measurements of the dissolved Fe concentrations in the stock solution and in the reacted solutions, respectively. The adsorbents were filtered $(0.45 \mu \mathrm{m}$, Sartorius, cellulose acetate) and washed several times with ultrapure water. The obtained solids were dried at $313 \mathrm{~K}$ for 3 days and subsequently gently desegregated using an agate mortar and a pestle. The iron(III) oxide coated adsorbents are hereafter referred to as FeO-ALO, FeO-BEI and FeO-ZEO.

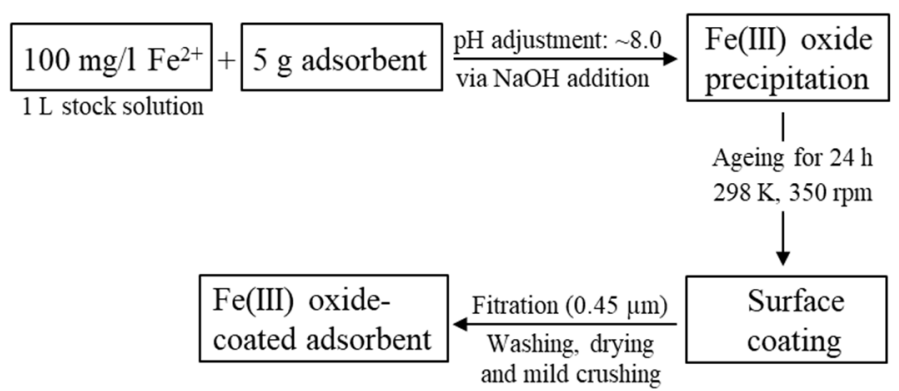

Figure 1. Flow chart showing the preparation of the Fe(III) oxide-coated adsorbents.

\subsection{Adsorption Experiments}

Stock solutions containing $\mathrm{Ba}^{2+}$ in different concentrations were prepared by the dissolution of barium chloride dihydrate $\left(\mathrm{BaCl}_{2} \cdot 2 \mathrm{H}_{2} \mathrm{O}, \geq 99 \%\right.$, from Roth) in ultrapure water. Batch experiments were conducted at $298 \mathrm{~K}$ using a fluid/solid ratio of 500:1 unless otherwise stated.

The effect of contact time on the adsorption of aqueous $\mathrm{Ba}^{2+}$ by the (FeO-treated) adsorbents was studied at $\mathrm{pH} 6.0 \pm 0.2 \mathrm{pH}$ units. The kinetic experiments were conducted in $1.5 \mathrm{~L}$ high-density polyethylene reactors containing $1 \mathrm{~L}$ of the adsorbate $\left(10 \mathrm{mg} / \mathrm{L} \mathrm{Ba}^{2+}\right)$ and $2.0 \mathrm{~g}$ of the adsorbent. Fluid samples $(1.5 \mathrm{~mL})$ were taken regularly after $30 \mathrm{~s}, 2 \mathrm{~min}, 5 \mathrm{~min}, 10 \mathrm{~min}, 30 \mathrm{~min}, 2 \mathrm{~h}$ and $24 \mathrm{~h}$ using a syringe (Omnifix ${ }^{R}$ Solo, B.Braun, Maria Enzersdorf, Austria). The liquids were filtered via $0.45 \mu \mathrm{m}$ cellulose acetate membranes (Sartorius) and acidified using concentrated $\mathrm{HNO}_{3}$ of suprapure grade (Roth, ROTIPURAN ${ }^{\mathrm{R}}$, Roth, Karlsruhe, Germany).

The effect of $\mathrm{pH}$ on the removal efficiency of aqueous $\mathrm{Ba}^{2+}$ by (FeO-treated) adsorbents was investigated by reacting $0.4 \mathrm{~g}$ of the adsorbent with $200 \mathrm{~mL}$ of a solution containing $10 \mathrm{mg} / \mathrm{L} \mathrm{Ba}^{2+}$. The $\mathrm{pH}$ of the suspensions was adjusted to $\mathrm{pH} 9.0 \pm 0.1$ with $0.1 \mathrm{M} \mathrm{NaOH}$ solutions. The suspensions were stirred at $300 \mathrm{rpm}$ for $1 \mathrm{~h}$ to achieve equilibrium conditions. Then, droplets of a $0.05 \mathrm{M} \mathrm{HCl}$ solution were added to the suspension to induce a $\mathrm{pH}$ decrease from 9.0 to 3.0, each \pm 0.1 . Fluid samples $(1.5 \mathrm{~mL})$ were taken every $0.5-0.7 \mathrm{pH}$ unit steps. These $\mathrm{pH}$ drift experiments were of short duration $(<2-3 \mathrm{~h})$ to reduce changes in the surface area and charge distribution of the adsorbents.

The effect of the initial $\mathrm{Ba}^{2+}$ concentration was studied at $\mathrm{pH} 6.0 \pm 0.2$ for $24 \mathrm{~h}$ using $50 \mathrm{~mL}$ of solution containing $\mathrm{Ba}^{2+}$ in different concentrations $(5,10,25,50,100$ and $200 \mathrm{mg} / \mathrm{L}$ ) and $0.1 \mathrm{~g}$ of the adsorbent. The experiments were carried out in triplicate at $283 \mathrm{~K}, 298 \mathrm{~K}$ and $313 \mathrm{~K}$ in order to study further the effect of temperature on the isotherms.

For the competitive ion tests, local river water (collected from the river Mur, Graz, Austria) was filtered via a $0.45 \mu \mathrm{m}$ cellulose acetate membrane (Sartorius, Göttingen, Germany). To prevent from the precipitation of Ba-sulfate or Ba-carbonate minerals during the adsorption experiments, the river water was treated as follows: Aqueous $\mathrm{SO}_{4}{ }^{2-}$ originally present in the river water was removed by the 
titration with a $0.5 \mathrm{M} \mathrm{BaCl}_{2}$ solution to induce barite $\left(\mathrm{BaSO}_{4}\right)$ precipitation. This chemical precipitate was separated by filtration $(0.45 \mu \mathrm{m}$, Sartorius, cellulose acetate). The solution was then adjusted to a $\mathrm{pH}$ of 3.0 by the titration with $0.1 \mathrm{M} \mathrm{HCl}$ solutions to induce degassing of $\mathrm{CO}_{2}$, thus preventing from the precipitation of witherite $\left(\mathrm{BaCO}_{3}\right)$. Prior to the competitive cation experiments, the $\mathrm{pH}$ of the modified river water was readjusted to 6.0 by the addition of $0.1 \mathrm{M} \mathrm{NaOH}$ solutions and the aqueous $\mathrm{Ba}^{2+}$ concentration set to $40 \mathrm{mg} / \mathrm{L}$ by the addition of highly concentrated ( $3.5 \mathrm{M}) \mathrm{BaCl}_{2}$ solutions. Afterwards, $0.1 \mathrm{~g}$ of the adsorbent was reacted with $50 \mathrm{~mL}$ of the modified river water for $24 \mathrm{~h}$. In an experimental subset, the adsorbent mass was increased to $0.5 \mathrm{~g}$ in order to assess the optimum adsorbent dosage.

The regenerability of the adsorbents was evaluated in adsorption-desorption cycles. Therefore, $0.1 \mathrm{~g}$ of adsorbent was reacted with $50 \mathrm{~mL}$ of a solution containing $10 \mathrm{mg} / \mathrm{L} \mathrm{Ba}^{2+}$ and let to equilibrate for $0.5 \mathrm{~h}$ at $\mathrm{pH}$ 6.0. Desorption of $\mathrm{Ba}^{2+}$ was induced by pipetting two drops of a $1 \mathrm{M} \mathrm{HCl}$ solution to yield a $\mathrm{pH}$ of $3.0 \pm 0.2$, following equilibration of the experiments for $0.5 \mathrm{~h}$, and then readjusting the suspension to $\mathrm{pH} 6.0 \pm 0.1$ by the addition of two drops of a $1 \mathrm{M} \mathrm{NaOH}$ solution to induce $\mathrm{Ba}^{2+}$ adsorption, and waiting for another $0.5 \mathrm{~h}$. Liquid samples $(1 \mathrm{~mL})$ were taken after the establishment of adsorption equilibrium at $\mathrm{pH} 3.0$ and 6.0. Five adsorption-desorption cycles were carried out. The regenerability experiments were of relatively short duration (e.g., 5-6 h) to minimize changes in the physicochemical properties of the adsorbents.

The amount of aqueous $\mathrm{Ba}^{2+}$ adsorbed by the different (FeO-treated) adsorbents $\left(\mathrm{q}_{\mathrm{e}}\right.$ in $\mathrm{mg} / \mathrm{g}$ ) was calculated using Equation (1):

$$
\mathrm{q}_{\mathrm{e}}=\frac{\left(\mathrm{C}_{0}-\mathrm{C}_{\mathrm{e}}\right)}{\mathrm{m}} \times \mathrm{V}
$$

where $C_{0}$ and $C_{e}$ are the initial and the equilibrium concentrations of the adsorbate (in mg/L), $m$ denotes the dry mass of the adsorbent (in $\mathrm{g}$ ) and $\mathrm{V}$ is the volume of the solution (in $\mathrm{L}$ ).

The efficiency of the adsorption was calculated using Equation (2):

$$
\% \text { removal }=\frac{\left(\mathrm{C}_{0}-\mathrm{C}_{\mathrm{e}}\right)}{\mathrm{C}_{0}} \times 100
$$

where \% removal refers to the percentage of removed adsorbate at equilibrium. Note here that the reproducibility of all results was determined in triplicate. Relative standard deviations were found to be always below $\pm 3 \%$. In the following, only the average values are reported.

\subsection{Analytical Methods}

\subsubsection{Fluid-Phase Characterization}

The $\mathrm{pH}$ of the experimental solution was measured at $298 \mathrm{~K}$ with a SenTix 41 glass electrode connected to a WTW Multi 350i (Xylem Analytics, Weilheim, Germany), which was calibrated via NIST buffer standard solutions at $\mathrm{pH} 4.01,7.00$ and 10.00 (analytical error: $\pm 0.05 \mathrm{pH}$ units).

The aqueous concentrations of $\mathrm{Al}, \mathrm{Ba}, \mathrm{Ca}, \mathrm{Fe}, \mathrm{K}, \mathrm{Mg}, \mathrm{Na}$ and $\mathrm{Si}$ were analyzed in acidified samples ( $2 \% \mathrm{HNO}_{3}$ matrix) by inductively coupled plasma optical emission spectroscopy (ICP-OES) using a PerkinElmer Optima 8300 (Waltham, MA, USA). The concentration range considered in the ICP-OES analyses ranged from $1 \times 10^{-3}$ to $5 \times 10^{2} \mathrm{mg} / \mathrm{L}$, depending on the analyte type. Detections limits are always below $1 \mu \mathrm{g} / \mathrm{L}$ for the elements of interest. NIST 1640a, in-house and SPS-SW2 Batch 130 standards were measured at the beginning, at the end and in between individual sample sequences [13]. The analytical error is $\pm 2 \%$ for $\mathrm{Mg}$ and $\mathrm{Na}$ and $\pm 3 \%$ for $\mathrm{Al}, \mathrm{Ba}, \mathrm{Ca}, \mathrm{Fe}, \mathrm{K}$ and Si analyses, respectively (2 SD, 3 replicates for each sample).

The aqueous speciation of $\mathrm{Ba}$ in solution and the saturation degrees of relevant Ba-bearing minerals, such as Ba-(hydr)oxides, Ba-chloride hydrates and Ba-silicates, were computed with the PHREEQC software and its implemented Lawrence Livermore National Laboratory (LLNL) database at the experimental $\mathrm{pH}$ and temperature $[29,30]$. 


\subsubsection{Solid-Phase Characterization}

The mineralogical composition of the (FeO-treated) adsorbents was investigated by powder $X$-ray diffraction (P-XRD). The materials were prepared in XRD sample holders using the top-loading technique and examined in the range $5-85^{\circ} 2 \theta$ with a step size of $0.008^{\circ} 2 \theta$ and a count time of $40 \mathrm{~s} \mathrm{per}$ step using a X'Pert PRO diffractometer (PANalytical, Almelo, The Netherlands) operated at $40 \mathrm{kV}$ and $40 \mathrm{~mA}(\mathrm{Co}-\mathrm{K} \alpha)$ and fitted with a high-speed Scientific $\mathrm{X}^{\prime}$ Celerator detector. Mineral identification and mineral quantification were carried out by Rietveld refinement of the P-XRD patterns using the X'Pert Highscore Plus software (version 2.2e, PANalytical, Almelo, The Netherlands) and the pdf-4 database (analytical uncertainty: $\pm 3 \mathrm{wt} \%$; [31]).

Attenuated total reflectance-Fourier transform infrared spectroscopy (ATR-FTIR) data were acquired on a PerkinElmer Frontier spectrometer (Waltham, MA, USA) for the characterization of the poorly crystallized components present in the (FeO-treated) adsorbents. Mid-infrared (MIR) spectra were recorded in the range from $4000-650 \mathrm{~cm}^{-1}$ at a resolution of $2 \mathrm{~cm}^{-1}$.

The chemical composition of the raw materials was analyzed by wavelength dispersive $\mathrm{X}$-ray fluorescence (XRF) spectrometry using a PW2404 (PANalytical, Almelo, The Netherlands). Therefore, the loss on ignition (LOI) was determined by gravimetric analysis. Standard glass tablets were produced by fusion in a PANalytical Perl' $X 3$ bead preparation system (Malvern PANalytical) using $6.0 \mathrm{~g}$ of $\mathrm{Li}_{2} \mathrm{~B}_{4} \mathrm{O}_{7}$ as fluent agent. The analytical error is $<0.5 \mathrm{wt} \%$ for the major elements [32].

The particle shape and the size of the (FeO-treated) adsorbents were characterized by scanning electron microscopy (SEM). The materials were prepared on Al-stubs, coated with Au-Pd and imaged by a DSM 982 Gemini microscope (ZEISS, Oberkochen, Germany) operated at $5 \mathrm{kV}$ of accelerating voltage. Element distribution mappings ( $\mathrm{Al}, \mathrm{Si}, \mathrm{Fe}, \mathrm{Ba}$, etc.) were acquired on a Sigma $300 \mathrm{VP}$ (ZEISS, Oberkochen, Germany) operated at $15 \mathrm{kV}$ and equipped with a X-max80 SDD energy dispersive X-ray spectroscopy (EDX, Oxford Instrument, Abingdon, UK) detector. Chemical data were acquired on selected single spots per sample at an analytical precision of $<2$ at $\%$ for the elements of interest ( $\mathrm{Al}, \mathrm{Si}$, $\mathrm{Fe}$, etc.).

The specific surface area of natural and FeO-modified adsorbents was determined before and after the Ba adsorption by $\mathrm{N}_{2}$ physisorption using the single-point adsorption BET method (e.g., [33]) in order to track changes in the surface properties of the adsorbents. All materials were pre-dried as stated above. The measurements were carried out on a Micrometrics FlowSorb II 2300 using a $\mathrm{He}(69.8)-\mathrm{N}_{2}$ (30.2) mixture as the carrier gas at the Institute of Technology and Testing of Construction Materials at Graz University of Technology. The analytical error was determined as $\pm 10 \%$.

\section{Results and Discussion}

\subsection{Mineralogical Composition of the Adsorbents}

XRD patterns of the adsorbents used in this study are displayed in Figure 2. The mineralogy of the raw (and FeO-modified) materials is reported in Table 1.

ALO consists of allophane (70 $\mathrm{wt} \%$ ), which displays two broad and asymmetric reflections centered at $30.50^{\circ} 2 \theta$ and $45.75^{\circ} 2 \theta$, which is typical for this short-range-order mineral phase. Minor constituents in ALO are quartz $(7 \mathrm{wt} \%)$, halloysite $(5 \mathrm{wt} \%)$, cristobalite, gibbsite, hornblende (each $4 \mathrm{wt} \%$ ) and goethite (3 wt\%). Illite, feldspar (mainly albite-type) and Mg-chlorite (clinochlore) are present as traces $(1 \mathrm{wt} \%)$. BEI consists of beidellite $(91 \mathrm{wt} \%)$ as well as quartz $(5 \mathrm{wt} \%)$ and hematite $(4 \mathrm{wt} \%)$. The mineralogical composition of ZEO is based on a mixture of natrolite $(74 \mathrm{wt} \%)$ and stilbite $(26 \mathrm{wt} \%)$. No significant mineralogical changes of the adsorbents were observed after the FeO-modification, except for the $\mathrm{d}_{101}$-peak $\left(24.42^{\circ} 2 \theta\right)$ and $\mathrm{d}_{301}$-peak $\left(38.55^{\circ} 2 \theta\right)$ of goethite and the $\mathrm{d}_{014}$-peak of hematite $\left(38.68^{\circ} 2 \theta\right)$, which gained intensity (see inserted figures in Figure 2 ). 

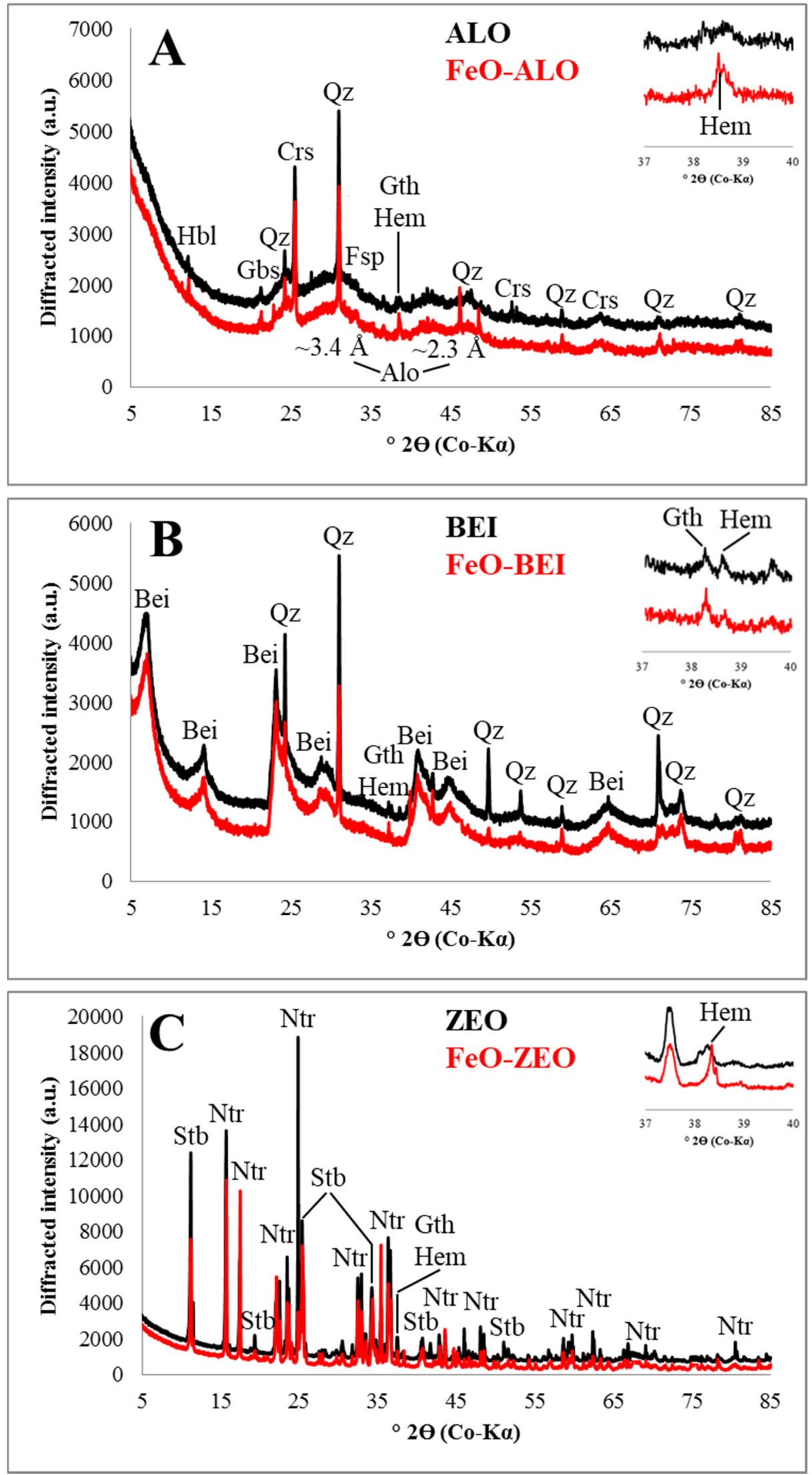

Figure 2. XRD patterns of natural and FeO-modified ALO (A), BEI (B) and ZEO (C). Hbl—hornblende; Gbs-gibbsite; Qz-quartz; Crs—cristobalite; Fsp-feldspar; Alo-allophane; Gth-goethite; Hem-hematite; Bei-beidellite; Stb—stilbite; Ntr—natrolite. 
Table 1. Mineralogical composition of ALO, BEI and ZEO used as adsorbents.

\begin{tabular}{cccc}
\hline Phase (wt\%) & ALO & BEI & ZEO \\
\hline Allophane & 70 & - & - \\
Beidellite & - & 91 & - \\
Clinochlore & 1 & - & - \\
Cristobalite & 4 & - & - \\
Feldspar & 1 & - & - \\
Quartz & 7 & 5 & - \\
Gibbsite & 4 & - & - \\
Goethite & 3 & - & - \\
Halloysite & 5 & - & - \\
Hematite & - & 4 & - \\
Hornblende & 4 & - & - \\
Illite & 1 & - & - \\
Natrolite & - & - & 74 \\
Stilbite & - & - & 26 \\
SUM & 100 & 100 & 100 \\
\hline
\end{tabular}

XRD patterns of the adsorbents collected after the adsorption experiments are identical to those of the unreacted materials (see Supplementary Material Figure S1). Importantly, they do not reveal the presence of discrete Ba-bearing minerals due to the low $\mathrm{Ba}^{2+}$ concentration relative to the adsorbents mass. This observation may indicate that sorption is the main mechanism governing $\mathrm{Ba}^{2+}$ uptake from solution.

MIR spectra of the adsorbents with and without FeO-modification are displayed in Figure 3.

ALO and FeO-ALO consist mainly of allophane, as indicated by the strong lattice vibration bands in the region between 1000 and $900 \mathrm{~cm}^{-1}$ due to $\mathrm{Si}-\mathrm{O}-(\mathrm{Si})$ or $\mathrm{Si}-\mathrm{O}-(\mathrm{Al})$ vibrations and at $870 \mathrm{~cm}^{-1}$ due to $\mathrm{Si}-\mathrm{OH}$ groups [17,34]. Quartz occurs in minor quantities and was identified based on a diagnostic IR band in the lattice vibration region at $798 \mathrm{~cm}^{-1}$ [13]. BEI and FeO-BEI display two strong IR bands at $3697 \mathrm{~cm}^{-1}$ and $3621 \mathrm{~cm}^{-1}$, corresponding to hydroxyl groups associated with octahedral cations in beidellite. The broadness of the $3621 \mathrm{~cm}^{-1}$ band documents the substitution of $\mathrm{Al}^{3+}$ by $\mathrm{Fe}^{2+}$ or $\mathrm{Mg}^{2+}$ cations in the octahedral sheet of beidellite, which is further seen by the bending vibrations of hydroxyl groups associated with these octahedral cations at $908 \mathrm{~cm}^{-1}(\mathrm{Al}-\mathrm{Al}-\mathrm{OH}), 876 \mathrm{~cm}^{-1}(\mathrm{Al}-\mathrm{Fe}-\mathrm{OH})$ and $834 \mathrm{~cm}^{-1}$ (Al-Mg-OH) [35]. The IR bands at $1120 \mathrm{~cm}^{-1}, 1022 \mathrm{~cm}^{-1}, 986 \mathrm{~cm}^{-1}$ and $798 \mathrm{~cm}^{-1}$ correspond to $\mathrm{Si}-\mathrm{O}$ stretching vibrations in beidellite and quartz, whereas the IR band at $747 \mathrm{~cm}^{-1}$ is most likely related to the stretching mode of Al-O-Al linkage [36]. The MIR spectra of ZEO and FeO-ZEO display strong adsorption in the hydroxyl stretching region at $3537 \mathrm{~cm}^{-1}$ and $3321 \mathrm{~cm}^{-1}$ and a weak one at $3615 \mathrm{~cm}^{-1}$, which are attributed to hydroxyl stretching vibrations in zeolitic water in natrolite and stilbite [37]. Numerous and intense IR bands in the lattice vibration region between 1200 and $900 \mathrm{~cm}^{-1}$ are due to $\mathrm{Si}-\mathrm{O}-\mathrm{Si}$ and $\mathrm{Si}-\mathrm{O}-\mathrm{Al}$ stretching vibrations. The IR band at $720 \mathrm{~cm}^{-1}$ corresponds to the 4-membered rings in the tetrahedral framework of zeolite structures [37]. IR spectra of the materials obtained after the adsorption experiments (Supplementary Material Figure S2) look similar to those of the unreacted adsorbents, except for the ZEO and FeO-ZEO, which displayed minor modifications in the lattice vibration region. 

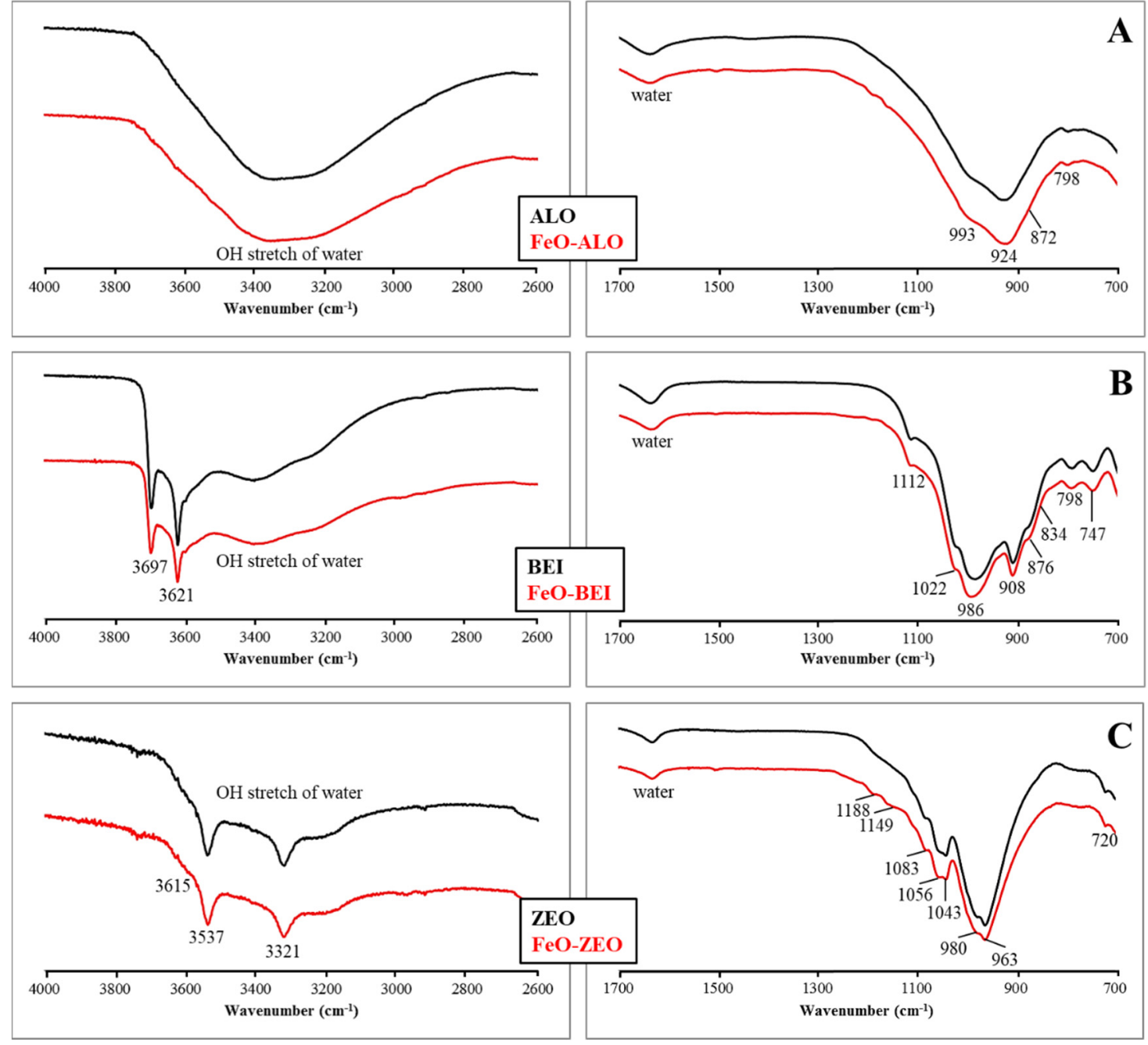

Figure 3. ATR-FTIR spectra of natural and FeO-modified ALO (A), BEI (B) and ZEO (C). Left panel) Hydroxyl stretching region. Right panel) Lattice vibration region.

\subsection{Geochemical and Microstructural Characterization of the Adsorbents}

The chemical compositions of the adsorbents before and after FeO-modification are reported in Table 2. Representative SEM images of these adsorbents are presented in Figure 4.

Table 2. Chemical composition of ALO, BEI and ZEO. During the FeO-modification about $2.5 \mathrm{wt} \%$ of $\mathrm{Fe}_{2} \mathrm{O}_{3}$ was added to each raw material (FeO-ALO, FeO-BEI and FeO-ZEO).

\begin{tabular}{cccc}
\hline Comp. $(\mathbf{w t} \%)$ & ALO & BEI & ZEO \\
\hline $\mathrm{LOI}$ & 31.7 & 15.3 & 13.6 \\
$\mathrm{Na}_{2} \mathrm{O}$ & 0.2 & 0.1 & 10.8 \\
$\mathrm{MgO}$ & 0.8 & 5.2 & - \\
$\mathrm{Al}_{2} \mathrm{O}_{3}$ & 27.4 & 22.2 & 23.2 \\
$\mathrm{SiO}_{2}$ & 31.1 & 47.7 & 49.0 \\
$\mathrm{P}_{2} \mathrm{O}_{5}$ & 0.0 & 0.6 & - \\
$\mathrm{K}_{2} \mathrm{O}$ & 0.1 & 0.1 & 0.2 \\
$\mathrm{CaO}$ & 0.4 & 1.5 & 3.1 \\
$\mathrm{TiO}$ & 0.9 & 0.2 & - \\
$\mathrm{MnO}$ & 0.1 & - & - \\
$\mathrm{Fe}_{2} \mathrm{O}_{3}$ & 7.3 & 7.2 & - \\
$\mathrm{SrO}$ & - & - & 0.3 \\
$\mathrm{SUM}$ & 100.0 & 100.0 & 99.9 \\
\hline
\end{tabular}



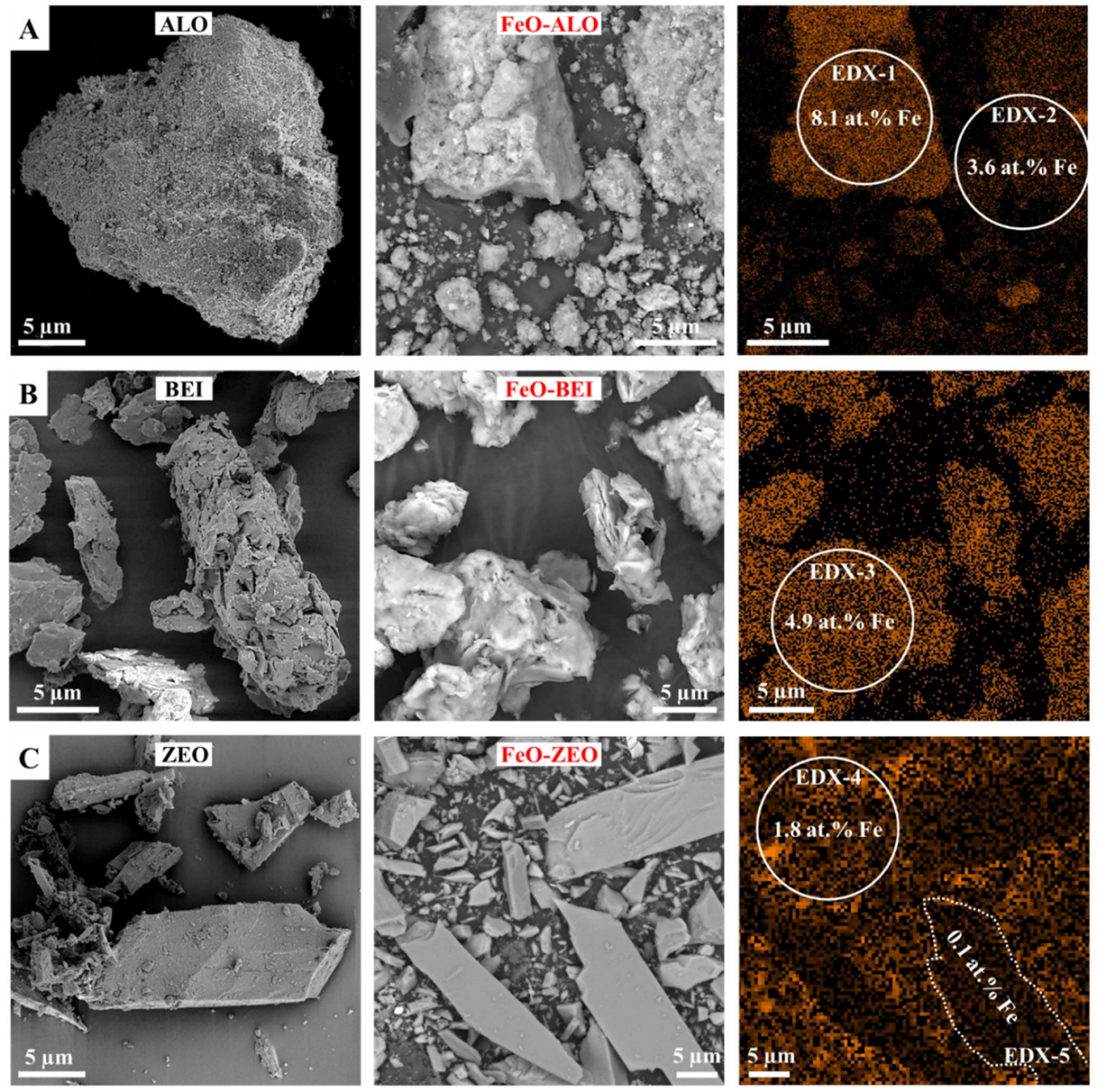

Figure 4. SEM images of natural (first panel) and FeO-modified (second panel) ALO (A), BEI (B) and ZEO (C) adsorbents. Fe distribution maps of the images shown in the second panel are provided on the right. Marked areas indicate positions of EDX measurements (Supplementary Material Figure S3).

ALO and particularly FeO-ALO display $\mu$ m-sized aggregates of clumped particles rich in allophane having goethite and hematite in different proportions attached onto the allophane surfaces. Individual allophane particles appear as hollow spherule structures. These particles have diameters of $3-5 \mathrm{~nm}$ and an atomic $\mathrm{Al} / \mathrm{Si}$ ratio of $1.3 \pm 0.2$, according to Baldermann et al. [13]. BEI and FeO-BEI are composed mainly of very fine grained $(<1 \mu \mathrm{m})$, veil-like to flaky or platy beidellite particles, $\left.\mathrm{Ca}_{0.13} \mathrm{Mg}_{0.20} \mathrm{Na}_{0.01} \mathrm{~K}_{0.01}\right)\left(\mathrm{Al}_{1.50} \mathrm{Mg}_{0.42} \mathrm{Fe}^{3+}{ }_{0.19}\right) \sum_{2.11}\left[\mathrm{Al}_{0.59} \mathrm{Si}_{3.41} \mathrm{O}_{10}\right](\mathrm{OH})_{2}$, having goethite and hematite grains attached on the surface, whose concentrations increase after the FeO-modification, as well as a few coarser quartz grains. ZEO and FeO-ZEO are mixtures of needle-shaped to fibrous crystals (1-30 $\mu \mathrm{m}$ in largest dimension) as well as short-prismatic crystals (5-20 $\mu \mathrm{m}$ in diameter) arranged in more compact aggregates. These characteristic particle morphologies can be assigned to natrolite and stilbite, respectively. The Fe distribution map of FeO-ZEO reveals a heterogeneous composition, with the smaller particles (i.e., stilbite) being relatively enriched in Fe and the coarser ones (i.e., natrolite) being depleted in Fe.

The surface areas of the adsorbents increase in the order: ZEO $\left(2.3 \mathrm{~m}^{2} / \mathrm{g}\right)<\mathrm{BEI}\left(50.3 \mathrm{~m}^{2} / \mathrm{g}\right)<$ ALO $\left(368.5 \mathrm{~m}^{2} / \mathrm{g}\right)$. No significant change in the surface areas was observed after the FeO-modification $( \pm 10 \%$ change, which is within the analytical uncertainty of the method) due to the low amounts of Fe added to the adsorbents $\left(2.5 \% \mathrm{Fe}_{2} \mathrm{O}_{3}\right.$ by weight). The specific surface areas of all adsorbents measured after the $\mathrm{Ba}$ adsorption were found to be identical to those of the unreacted (raw and FeO-coated) materials 
( $5 \%$ change), which clearly indicates that changes in the physical properties of the adsorbents during the duration of the experiments are negligible.

\subsection{Adsorption Studies}

\subsubsection{Aqueous Speciation of Barium}

The affinity between an adsorbent and an adsorbate is an important parameter that controls the extent and rate of an adsorption process [13]. Previous adsorption studies have shown that the aqueous speciation of a given metal ion, solution $\mathrm{pH}$, contact time, temperature, the presence or absence of competitive ions and the metal ion concentration among others are key variables for determining the efficiency, kinetics and the mechanism of an adsorption reaction $[7,9,38]$. As for this study, these factors control the speed and the magnitude at which aqueous $\mathrm{Ba}^{2+}$ gets attached onto ALO, BEI and ZEO with (out) FeO-modification.

In all experiments, the aqueous speciation of Ba was predominated by "free" $\mathrm{Ba}^{2+}$ ions $(>99 \%)$ in the $\mathrm{pH}$ range from 9.0 to 3.0 and only less than $2 \%$ of the total $\mathrm{Ba}$ species belonged to the $\mathrm{BaCl}^{+}$and $\mathrm{BaOH}^{+}$aquo-complexes, demonstrating that (i) the vast majority of $\mathrm{Ba}^{2+}$ in solution prevailed in the cationic form and (ii) the aqueous speciation of Ba did not change during the $\mathrm{pH}$-drift experiments. In the case of the competitive ion test, the aqueous speciation of $\mathrm{Ba}, \mathrm{Ca}, \mathrm{K}, \mathrm{Mg}$ and $\mathrm{Na}$ was dominated by $\mathrm{Ba}^{2+}(>98 \%), \mathrm{Ca}^{2+}(>99 \%), \mathrm{K}^{+}(100 \%), \mathrm{Mg}^{2+}(>95 \%)$ and $\mathrm{Na}^{+}$ions $(>98 \%)$ over trace amounts of $\mathrm{BaCl}^{+}$ $(<2 \%), \mathrm{CaCl}^{+}(1 \%), \mathrm{MgCl}^{+}(<5 \%)$ and $\mathrm{NaCl}(<2 \%)$ aquo-complexes. All aqueous solutions were at any time undersaturated with respect to the various Ba-bearing mineral phases, such as barite, witherite, barytocalcite $\left(\mathrm{BaCa}\left(\mathrm{CO}_{3}\right)_{2}\right)$, sanbornite $\left(\mathrm{BaSi}_{2} \mathrm{O}_{5}\right)$, barium hydroxide monohydrate $\left(\mathrm{Ba}(\mathrm{OH})_{2} \cdot \mathrm{H}_{2} \mathrm{O}\right)$ and barium hydroxide octahydrate $\left(\mathrm{Ba}(\mathrm{OH})_{2} \cdot 8 \mathrm{H}_{2} \mathrm{O}\right)$, corroborating the XRD and FTIR results.

\subsubsection{Kinetics Experiments}

The kinetics of the adsorption of aqueous $\mathrm{Ba}^{2+}$ by ALO, FeO-ALO, BEI, FeO-BEI, ZEO and $\mathrm{FeO}-\mathrm{ZEO}$ at $\mathrm{pH} 6.0$ and room temperature are presented in Figure 5. In the first minutes of contact time, the uptake of $\mathrm{Ba}^{2+}$ from solution increased rapidly, because of abundant binding sites at the surface of the different adsorbents. However, it slowed down afterwards due to (i) a decrease in the aqueous $\mathrm{Ba}^{2+}$ concentration with time, (ii) a lowering of the concentration difference between the bulk solution and the adsorbent-liquid interface and (iii) a decrease of available binding sites at the surface of the adsorbents as the adsorption process continued [39]. Thus, the results of the kinetics experiments indicate that the adsorption of aqueous $\mathrm{Ba}^{2+}$ by all adsorbents is a heterogeneous process, with an initial fast adsorption followed by a slower one. The kinetics of the $\mathrm{Ba}^{2+}$ adsorption by all adsorbents with(out) FeO-modification were fitted by a pseudo-first-order (PFO) model (Equation (3)):

$$
\ln \left(\mathrm{q}_{\mathrm{e}}-\mathrm{q}_{\mathrm{t}}\right)=-\mathrm{k} \cdot \mathrm{t}+\ln \left(\mathrm{q}_{\mathrm{e}}\right)
$$

where $\mathrm{q}_{\mathrm{e}}$ and $\mathrm{q}_{\mathrm{t}}$ are the amounts of $\mathrm{Ba}^{2+}$ taken up from solution per mass of adsorbent $(\mathrm{mg} / \mathrm{g})$ at equilibrium and at time $t(\mathrm{~min})$ and $\mathrm{k}(1 / \mathrm{min})$ is the rate constant [40]. Note that the plot of Equation (3) was linear for all adsorbents and that and the calculated and measured $\mathrm{q}_{\mathrm{e}}$ values matched very well (slope: $0.968 ; \mathrm{R}^{2}=0.955 ; n=6$ ), which (i) clearly demonstrated the applicability of the PFO model to fit the experimental data and (ii) revealed that the removal of $\mathrm{Ba}^{2+}$ from solution follows physical adsorption. The calculated values for $\mathrm{k}$ and $\mathrm{q}_{\mathrm{e}}$ as well as the removal efficiency and the measured $\mathrm{q}_{\mathrm{e}}$ values are reported in Table 3.

It can be concluded that $\mathrm{Ba}^{2+}$ removal from solution by all adsorbents was a relatively fast process, which increased in the order: FeO-ZEO and ZEO (30 min) < BEI and ALO (10 min) < FeO-BEI and FeO-ALO (5-10 min). This indicates that BEI and ALO with and without FeO-modification have a higher affinity to adsorb $\mathrm{Ba}^{2+}$ ions than ZEO and FeO-ZEO, which is likely related to abundant $\equiv \mathrm{Si}-\mathrm{OH}$ and especially $\equiv \mathrm{Al}-\mathrm{OH}$ groups present in the clayey adsorbents (e.g., [13,41]). FeO-ZEO and ZEO hardly follow pseudo-first-order kinetics, although the calculated $R^{2}$ values are high $(>0.96$ and 0.99$)$ 
and the measured and calculated qe values are consistent (Table 3), which suggests that the removal mechanism for $\mathrm{Ba}^{2+}$ ions is more complex. It is proposed that initial adsorption corresponded mainly to ion exchange in surface-related micropores, followed by the diffusion of $\mathrm{Ba}^{2+}$ into zeolite channels, where they occupied the exchangeable sites $\left(\mathrm{Na}^{+}, \mathrm{Ca}^{2+}\right.$ and $\left.\mathrm{K}^{+}\right)$within the zeolite crystal structure [39].
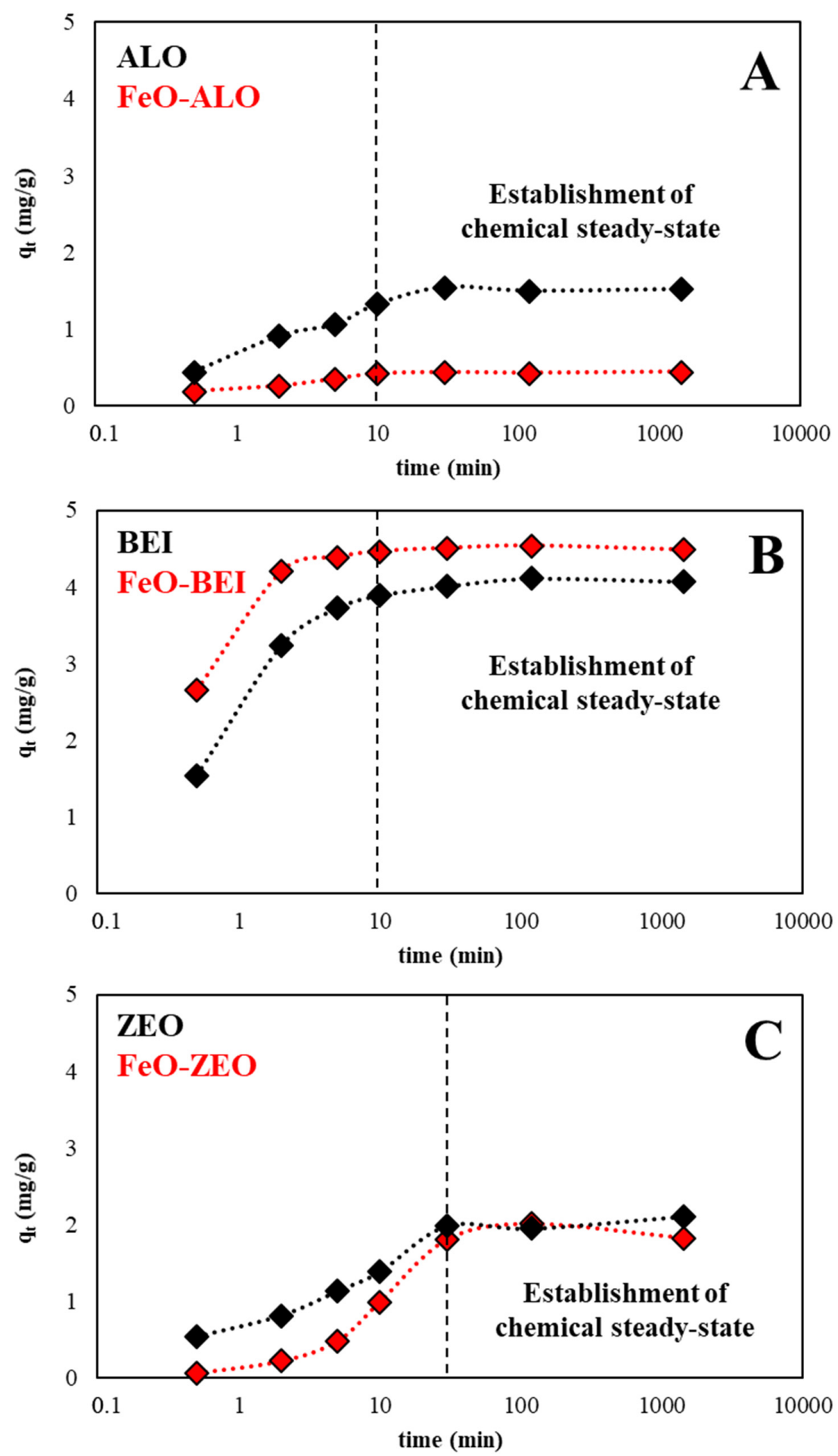

Figure 5. Kinetics experiments (operational conditions: 298 K, pH 6.0, adsorbate/adsorbent ratio: 500:1, $10 \mathrm{mg} / \mathrm{L} \mathrm{Ba}$ ). The effect of contact time on the adsorption of aqueous $\mathrm{Ba}^{2+}$ by natural and FeO-modified $\mathrm{ALO}(\mathbf{A}), \mathrm{BEI}(\mathbf{B})$ and ZEO (C) is shown. 
Table 3. Summary of the kinetics experiments. Reported are the equilibration time, the removal efficiencies, the measured $\left(\mathrm{q}^{\dagger}\right)$ and calculated $\left(\mathrm{q}^{\ddagger}\right)$ adsorption capacities and the kinetic parameters for the adsorption of $\mathrm{Ba}^{2+}$ by ALO, BEI and ZEO with(out) FeO-modification.

\begin{tabular}{ccccccc}
\hline & & \multicolumn{5}{c}{ Pseudo-First Order Parameters } \\
\hline Adsorbent & Equil. Time & $\mathbf{q}^{\dagger}$ & Removal Efficiency & $\mathbf{k}$ & $\mathbf{q e}^{\ddagger}$ & $\mathbf{R}^{\mathbf{2}}$ \\
\hline Material & $\mathbf{( m i n )}$ & $\mathbf{( m g / g )}$ & $\mathbf{( \% R e m o v a l )}$ & $\mathbf{( 1 / m i n )}$ & $\mathbf{( m g / g )}$ & $\mathbf{( - )}$ \\
\hline ALO & 10 & 1.5 & 30.5 & 0.185 & 1.2 & 0.940 \\
FeO-ALO & 5 & 0.4 & 8.8 & 0.308 & 0.8 & 0.981 \\
BEI & 10 & 4.0 & 80.6 & 0.787 & 3.6 & 0.983 \\
FeO-BEI & 5 & 4.5 & 89.6 & 1.266 & 3.6 & 0.970 \\
ZEO & 30 & 2.0 & 40.3 & 0.060 & 1.8 & 0.963 \\
FeO-ZEO & 30 & 1.9 & 37.6 & 0.065 & 2.1 & 0.999 \\
\hline
\end{tabular}

It can also be seen that the contribution of additional $\equiv \mathrm{Fe}-\mathrm{OH}$ groups, as the result of the FeO-modification, did not significantly increase the adsorption, although such surface sites can attract cations both via electrostatic interaction and surface complexation [42]. However, in view of the removal efficiency of aqueous $\mathrm{Ba}^{2+}$ at equilibrium, BEI and FeO-BEI performed about 2-times better than ZEO and FeO-ZEO and about 3-times better than ALO and FeO-ALO. This finding suggests further that the surface area measured for the different adsorbents has only a minor influence on the speed and magnitude of the adsorption process, which corroborates prior conclusions drawn by, e.g., Baldermann et al. [13].

\subsubsection{Effect of Solution $\mathrm{pH}$ on $\mathrm{Ba}^{2+}$ Removal}

The solution $\mathrm{pH}$ is of great relevance for an adsorption process, because acidity affects (i) the aqueous speciation of the adsorbate, which is $\mathrm{Ba}^{2+}$ in all experiments conducted in this study, (ii) the (de)protonation degree of the surface functional $\equiv \mathrm{Al}-\mathrm{OH}$ and $\equiv \mathrm{Si}-\mathrm{OH}$ groups of the adsorbents $[13,41]$ and (iii) the charge distribution of the adsorbents [11]. The effect of solution $\mathrm{pH}$ on the adsorption of aqueous $\mathrm{Ba}^{2+}$ by ALO, BEI and ZEO with (out) FeO-modification is seen in Figure 6.

It is evident that the amount of $\mathrm{Ba}^{2+}$ adsorbed from solution increases with increasing $\mathrm{pH}$, because under acidic conditions the $\equiv \mathrm{Al}-\mathrm{OH}$ and $\equiv \mathrm{Si}-\mathrm{OH}$ groups are more protonated, meaning that most of the potential binding sites for $\mathrm{Ba}^{2+}$ are occupied by $\mathrm{H}^{+}$ions. As natural zeolites preferentially adsorb $\mathrm{H}^{+}$ions relative to metal ions and antibiotics $[39,43,44], \mathrm{Ba}^{2+}$ adsorption by ZEO and FeO-ZEO was low under strongly acidic conditions and increased slightly towards more alkaline conditions, reaching an adsorption optimum at $\mathrm{pH}$ 5.5-8.0 (17-22\% removal). ALO and FeO-ALO also revealed low adsorption of aqueous $\mathrm{Ba}^{2+}$ at $\mathrm{pH} \leq 4.0$ ( $\leq 20 \%$ removal) due to repulsive electrostatic forces between the protonated functional groups and $\mathrm{Ba}^{2+}$ ions [18,45], but attained a maximum at $\mathrm{pH} 7.0-8.5$ (90-97\% removal). This $\mathrm{pH}$-dependency of the adsorption of the ALO-based adsorbents is most likely attributable to the high amount of variable ( $\mathrm{pH}$-dependent) charges in natural allophanes [13]. BEI exhibited a good performance in the $\mathrm{pH}$ range from 4.0 to 8.5 (80-86\% removal). The decrease of $\mathrm{Ba}^{2+}$ adsorption at $\mathrm{pH} \leq 4.0$ can be best explained by the increasing attachment of $\mathrm{H}^{+}$ions onto the surface functional groups in BEI; thus, limiting the number of free binding sites where $\mathrm{Ba}^{2+}$ ions can get attached onto.

FeO-BEI revealed the highest removal efficiency of aqueous $\mathrm{Ba}^{2+}$ among all other adsorbents tested in this study (96-99.9\% removal at $\mathrm{pH} 3.5-8.5)$, which indicates that the surface FeO-coating was stable over a broad $\mathrm{pH}$ range, corroborating the results reported previously by Pawar et al. [46]. At $\mathrm{pH} \geq 8.5$, the increasing abundance of hydroxylated complexes of barium decreased the adsorption capacity for all adsorbents, which is consistent with observations made for other metal ions, such as $\mathrm{Cu}$ and $\mathrm{Pb}$ [47]. Alternatively, an increased dissolution of traces of reactive siliceous components naturally present in the adsorbents, such as volcanic glass, under alkaline conditions and subsequent formation of Ba-bearing (alumino) silicates onto the surface of the adsorbents could also reduce the 
efficiency of the adsorption process [13], even though such precipitates were not observed by XRD and FTIR analyses.
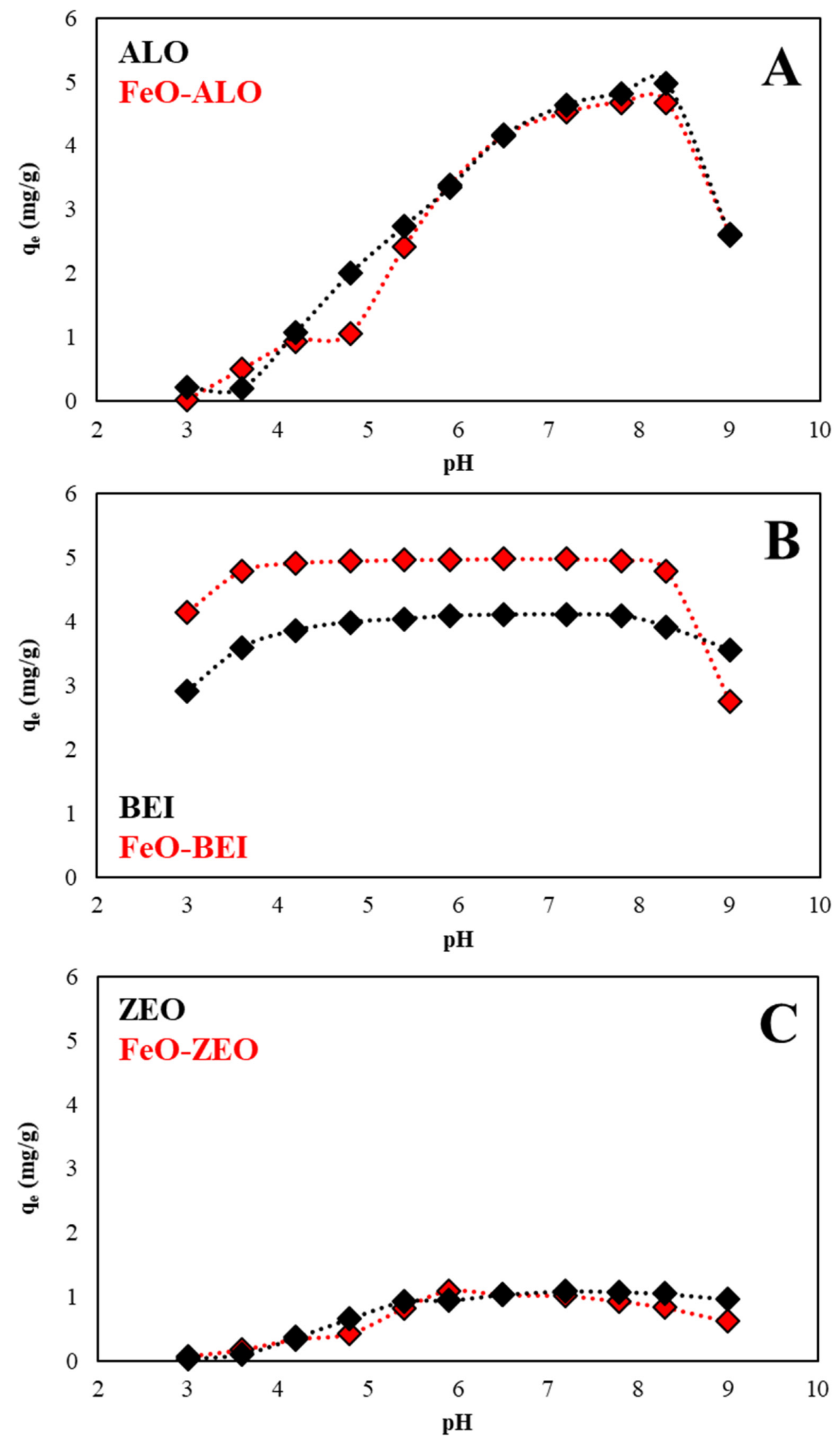

Figure 6. pH-drift experiments (operational conditions: $298 \mathrm{~K}$, adsorbate/adsorbent ratio: 500:1, $10 \mathrm{mg} / \mathrm{L} \mathrm{Ba}$ ). The effect of solution $\mathrm{pH}$ on the adsorption of aqueous $\mathrm{Ba}^{2+}$ by natural and FeO-modified $\mathrm{ALO}(\mathbf{A}), \mathrm{BEI}(\mathbf{B})$ and ZEO (C) is shown. 


\subsubsection{Effect of Initial $\mathrm{Ba}^{2+}$ Concentration}

Figure 7 shows the relation between the amount of $\mathrm{Ba}^{2+}$ adsorbed by ALO, BEI and ZEO with(out) FeO-modification and the initial concentration of $\mathrm{Ba}^{2+}$ in the solution. It is evident that when the $\mathrm{Ba}^{2+}$ concentration increased from 5 to $200 \mathrm{mg} / \mathrm{L}$, the qe values increased almost proportionally for all adsorbents. This indicates that the available binding sites became occupied, as the initial $\mathrm{Ba}^{2+}$ concentration increased. The FeO-modification had no effect (ALO and BEI) or even a negative one (ZEO) on the removal efficiencies of aqueous $\mathrm{Ba}^{2+}$.
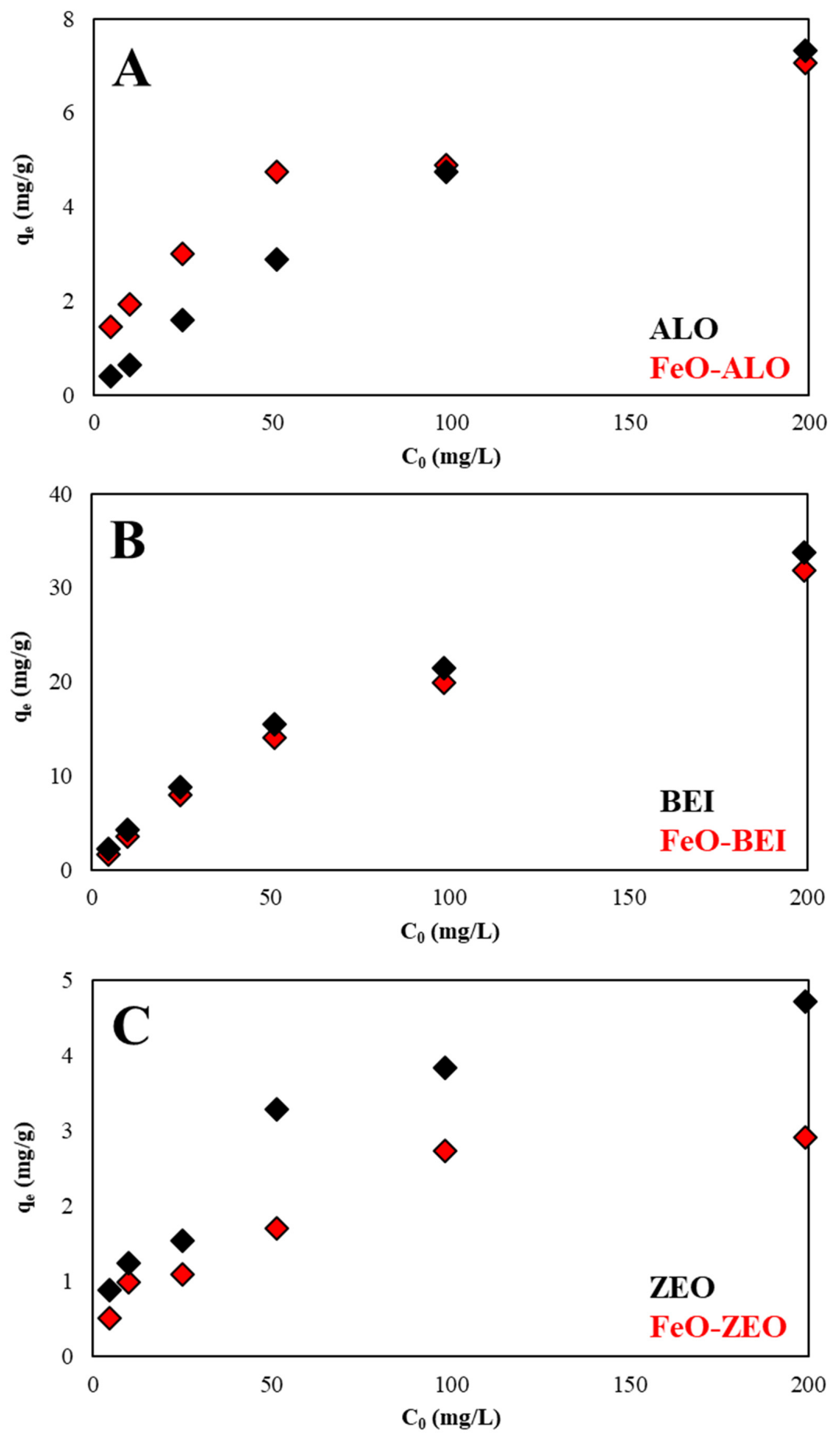

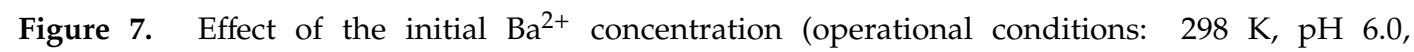
adsorbate/adsorbent ratio: 500:1, 5-200 mg/L Ba) on the adsorption of aqueous $\mathrm{Ba}^{2+}$ by natural and FeO-modified ALO (A), BEI (B) and ZEO (C). 


\subsubsection{Effect of Competing Cations}

In practice, waste solutions contain a mixture of different pollutants, such as critical metal ions (which is $\mathrm{Ba}$ in this case), as well as harmless solutes of different concentration and type, such as $\mathrm{Ca}^{2+}$, $\mathrm{Mg}^{2+}, \mathrm{Na}^{+}, \mathrm{K}^{+}$, etc. These cations have different affinities to adsorb onto charged surfaces, because of their different ionic properties, such as ion radius, charge, ionic potential, electronegativity, hydration state, hydration enthalpy, etc. [48]. As for this study, local river water contaminated with $\mathrm{Ba}^{2+}$ ions was used for the competitive cation tests, which fulfills the requirements mentioned above. Figure 8 shows the adsorption of cations from a multi-component solution.
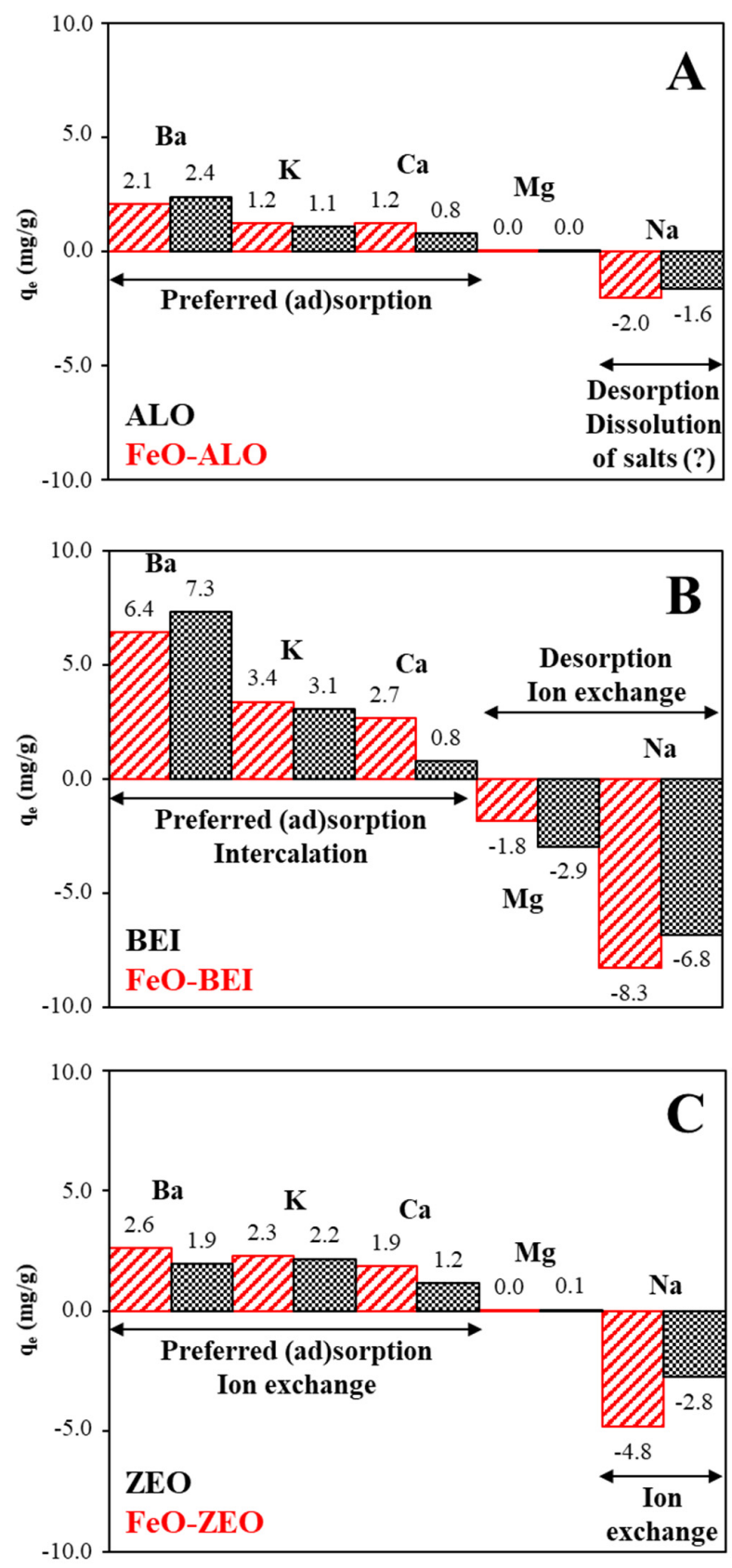

Figure 8. Effect of competing ions (operational conditions: $298 \mathrm{~K}, \mathrm{pH}$ 6.0, adsorbate/adsorbent ratio: $500: 1$, cations: $0.85 \mathrm{mmol} / \mathrm{L} \mathrm{Ca}^{2+}, 0.20 \mathrm{mmol} / \mathrm{L} \mathrm{Mg}^{2+}, 163.2 \mathrm{~mol} / \mathrm{L} \mathrm{Na}^{+}, 0.38 \mathrm{mmol} / \mathrm{L} \mathrm{K}^{+}$and $0.30 \mathrm{mmol} / \mathrm{L}$ $\mathrm{Ba}^{2+}$ ) on the adsorption of natural and FeO-modified ALO (A), BEI (B) and ZEO (C). 
The multi-component solution originally contained $0.85 \mathrm{mmol} / \mathrm{L} \mathrm{Ca}^{2+}, 0.20 \mathrm{mmol} / \mathrm{L} \mathrm{Mg}^{2+}$, $163.2 \mathrm{~mol} / \mathrm{L} \mathrm{Na}^{+}$(due to the readjustment of the $\mathrm{pH}$ by NaOH ), $0.38 \mathrm{mmol} / \mathrm{L} \mathrm{K}^{+}$and $0.30 \mathrm{mmol} / \mathrm{L} \mathrm{Ba}^{2+}$ (due to addition of $\mathrm{BaCl}_{2}$ solution). It can be seen that the cation uptake from solution followed in the order: $\mathrm{Ba}^{2+}>\mathrm{K}^{+}>\mathrm{Ca}^{2+}>>\mathrm{Mg}^{2+}$ for all adsorbents. The removal efficiency increased in the order: $\mathrm{ALO}<\mathrm{ZEO}<\mathrm{BEI}$. The FeO-modification neither changed the direction nor the magnitude of the adsorption. The $\mathrm{Na}^{+}$concentration increased relative to the river water, as did the $\mathrm{Mg}^{2+}$ concentration in the case of FeO-BEI and BEI, which expressed in negative $\mathrm{q}_{\mathrm{e}}$ values in Figure 8. This suggests that $\mathrm{Na}^{+}$ and also $\mathrm{Mg}^{2+}$ ions were released back to the solution upon uptake of the other cations. This behavior indicates that mechanisms other than pure adsorption have to be considered (see Section 3.3.9 for further discussion).

The experimental data indicate further that multiple adsorption cycles are needed to decrease the $\mathrm{Ba}^{2+}$ concentration in such multi-component solutions to the guideline limit of $0.7 \mathrm{mg} / \mathrm{L}$ (or $0.005 \mathrm{~mol} / \mathrm{L}$ ), as recommended by the $\mathrm{WHO}$ for $\mathrm{Ba}^{2+}$ in drinking water [49]. However, this result is indeed promising, if considering that the river water contained a great variety of other cations, which could have competed for the adsorption sites. An increase of the adsorbent dosage by 5-times $(0.1-0.5 \mathrm{~g})$ resulted in a decrease of the $\mathrm{Ba}^{2+}$ concentration to $0.03-0.04 \mathrm{mmol} / \mathrm{L}$ for BEI and FeO-BEI, $0.09-0.13 \mathrm{mmol} / \mathrm{L}$ for ALO and FeO-ALO and 0.22-0.24 mmol/L for ZEO and FeO-ZEO, respectively. An extrapolation of these data indicates that approximately $0.55-0.60 \mathrm{~g}$ of the BEI-based adsorbents are needed to decrease the $\mathrm{Ba}^{2+}$ concentration of the river water to below the WHO guideline limit.

\subsubsection{Adsorption Isotherms}

Adsorption isotherms define the relationship between the concentration of a component in a given aqueous solution and the quantity of the respective component adsorbed onto a solid surface at thermodynamic equilibrium and at constant temperature [46]. The adsorption data obtained in this study (Figure 9) were evaluated using the Langmuir model and the Dubinin-Radushkevich (D-R model) model. These models were chosen for the reasons discussed in detail in Tran et al. [40] and are represented by the Equations (4) and (5) (Langmuir, linear form) and 6-8 (D-R model, linear form), respectively:

$$
\begin{gathered}
\frac{\mathrm{C}_{\mathrm{e}}}{\mathrm{q}_{\mathrm{e}}}=\frac{1}{\mathrm{~K}_{\mathrm{L}} \cdot \mathrm{Q}_{\max }^{0}}+\frac{\mathrm{C}_{\mathrm{e}}}{\mathrm{Q}_{\max }^{0}} \\
\mathrm{R}_{\mathrm{L}}=\frac{1}{1+\mathrm{K}_{\mathrm{L}} \cdot \mathrm{C}_{0}} \\
\ln \left(\mathrm{q}_{\mathrm{e}}\right)=-\mathrm{K}_{\mathrm{DR}} \cdot \varepsilon^{2}+\ln \left(\mathrm{q}_{\mathrm{DR}}\right) \\
\varepsilon=\mathrm{R} \cdot \mathrm{T} \cdot \ln \left(1+\frac{1}{\mathrm{C}_{\mathrm{e}}}\right) \\
\mathrm{E}=\frac{1}{\sqrt{2 \cdot \mathrm{K}_{\mathrm{DR}}}}
\end{gathered}
$$

where $\mathrm{Q}_{\max }^{0}$ and $\mathrm{q}_{\mathrm{DR}}$ denote the monolayer adsorption capacity of an adsorbent $(\mathrm{mg} / \mathrm{g}), \mathrm{K}_{\mathrm{L}}(\mathrm{L} / \mathrm{mg})$ and $K_{\mathrm{DR}}\left(\mathrm{mol}^{2} / \mathrm{kJ}^{2}\right)$ are the Langmuir and D-R model adsorption constants, $\varepsilon$ is the Polanyi potential $\left(\mathrm{J}^{2} / \mathrm{mol}^{2}\right), \mathrm{R}$ is the universal gas constant $\left(8.314 \times 10^{-3} \mathrm{~kJ} /(\mathrm{mol} \cdot \mathrm{K})\right), \mathrm{T}$ is the temperature $(\mathrm{K}), \mathrm{R}_{\mathrm{L}}$ is the separation factor (i.e., a dimensionless constant that describes the nature of an adsorption process) and $\mathrm{E}(\mathrm{kJ} / \mathrm{mol})$ is the free energy change during the transfer of one mole of the adsorbate to the surface of the adsorbent. The values for $\mathrm{Q}_{\max }^{0}, \mathrm{~K}_{\mathrm{L}}$ and $\mathrm{R}_{\mathrm{L}}$ are reported in Table 4 . The values for $\mathrm{q}_{\mathrm{DR}}, \mathrm{K}_{\mathrm{DR}}$ and $\mathrm{E}$ are listed in Table 5, respectively. It can be seen that the experimental data are better described by the Langmuir model than by the $\mathrm{D}-\mathrm{R}$ model. The values of $\mathrm{R}_{\mathrm{L}}$ indicate the adsorption process to be favorable for all $\mathrm{Ba}^{2+}$ concentrations, temperatures and adsorbents tested in this study, if considering that an adsorption process is irreversible at $\mathrm{R}_{\mathrm{L}}=0$, favorable at $0<\mathrm{R}_{\mathrm{L}}<1$, linear at $\mathrm{R}_{\mathrm{L}}=1$ and unfavorable at $\mathrm{R}_{\mathrm{L}}>1$ [40]. 
Table 4. Summary of the Langmuir isotherm parameters and separation factors $\left(\mathrm{R}_{\mathrm{L}}\right)$ for the adsorption of aqueous $\mathrm{Ba}^{2+}$ by ALO, BEI and ZEO with (out) FeO-modification.

\begin{tabular}{cccccc}
\hline & \multicolumn{5}{c}{ Langmuir Parameters } \\
\hline Adsorbent & Temperature & $\mathbf{Q}^{\mathbf{0}}{ }_{\mathbf{m a x}}$ & $\mathbf{K}_{\mathbf{L}}$ & $\mathbf{R}^{\mathbf{2}}$ & $\mathbf{R}_{\mathbf{L}}$ \\
\hline Material & $\mathbf{( K )}$ & $\mathbf{( m g / g )}$ & $\mathbf{( L / m g}$ & $\mathbf{( - )}$ & $\mathbf{( - )}$ \\
\hline ALO & 288 & 11.4 & 0.006 & 0.935 & $0.42-0.97$ \\
ALO & 298 & 13.2 & 0.007 & 0.944 & $0.42-0.97$ \\
ALO & 313 & 16.8 & 0.014 & 0.945 & $0.26-0.93$ \\
\hline FeO-ALO & 288 & 3.0 & 0.031 & 0.987 & $0.14-0.86$ \\
FeO-ALO & 298 & 3.4 & 0.032 & 0.969 & $0.14-0.87$ \\
FeO-ALO & 313 & 4.6 & 0.036 & 0.977 & $0.12-0.85$ \\
\hline BEI & 288 & 33.1 & 0.025 & 0.984 & $0.17-0.89$ \\
BEI & 298 & 38.0 & 0.029 & 0.941 & $0.15-0.88$ \\
BEI & 313 & 44.8 & 0.034 & 0.993 & $0.13-0.85$ \\
\hline FeO-BEI & 288 & 29.4 & 0.044 & 0.989 & $0.10-0.82$ \\
FeO-BEI & 298 & 36.0 & 0.055 & 0.963 & $0.08-0.79$ \\
FeO-BEI & 313 & 38.6 & 0.058 & 0.945 & $0.19-0.90$ \\
\hline ZEO & 288 & 5.6 & 0.044 & 0.988 & $0.10-0.81$ \\
ZEO & 298 & 7.5 & 0.045 & 0.960 & $0.10-0.83$ \\
ZEO & 313 & 9.8 & 0.051 & 0.983 & $0.09-0.80$ \\
\hline FeO-ZEO & 288 & 4.9 & 0.026 & 0.996 & $0.16-0.88$ \\
FeO-ZEO & 298 & 5.4 & 0.032 & 0.966 & $0.14-0.87$ \\
FeO-ZEO & 313 & 9.6 & 0.033 & 0.972 & $0.29-0.94$ \\
\hline
\end{tabular}

Table 5. Summary of the Dubinin-Radushkevich parameters and mean free energy changes (E) of the adsorption of aqueous $\mathrm{Ba}^{2+}$ by ALO, BEI and ZEO with (out) FeO-modification.

\begin{tabular}{cccccc}
\hline & \multicolumn{5}{c}{ Dubinin-Radushkevich Parameters } \\
\hline Adsorbent & Temperature & qDR & $\mathbf{K}_{\mathbf{D R}}$ & $\mathbf{R}^{\mathbf{2}}$ & $\mathbf{E}$ \\
\hline Material & $\mathbf{( K )}$ & $\mathbf{( m g / g )}$ & $\left.\mathbf{( m o l}^{\mathbf{2}} \mathbf{/ k} \mathbf{J}^{\mathbf{2}}\right)$ & $\mathbf{( - )}$ & $\mathbf{( k J / m o l )}$ \\
\hline ALO & 288 & 5.1 & $3.94 \mathrm{E}-08$ & 0.943 & 3.6 \\
ALO & 298 & 5.3 & $3.63 \mathrm{E}-08$ & 0.923 & 3.7 \\
ALO & 313 & 9.2 & $2.77 \mathrm{E}-08$ & 0.934 & 4.3 \\
\hline FeO-ALO & 288 & 2.7 & $2.97 \mathrm{E}-08$ & 0.983 & 4.1 \\
FeO-ALO & 298 & 2.5 & $2.00 \mathrm{E}-08$ & 0.892 & 5.0 \\
FeO-ALO & 313 & 3.5 & $1.97 \mathrm{E}-08$ & 0.891 & 5.0 \\
\hline BEI & 288 & 22.2 & $2.31 \mathrm{E}-08$ & 0.974 & 4.70 \\
BEI & 298 & 25.8 & $2.11 \mathrm{E}-08$ & 0.979 & 4.9 \\
BEI & 313 & 35.7 & $2.29 \mathrm{E}-08$ & 0.988 & 4.7 \\
\hline FeO-BEI & 288 & 27.6 & $2.37 \mathrm{E}-08$ & 0.980 & 4.6 \\
FeO-BEI & 298 & 22.9 & $1.09 \mathrm{E}-08$ & 0.923 & 6.8 \\
FeO-BEI & 313 & 22.8 & $9.06 \mathrm{E}-09$ & 0.878 & 7.4 \\
\hline ZEO & 288 & 4.3 & $1.58 \mathrm{E}-08$ & 0.902 & 5.6 \\
ZEO & 298 & 5.4 & $1.27 \mathrm{E}-08$ & 0.871 & 6.3 \\
ZEO & 313 & 6.8 & $1.07 \mathrm{E}-08$ & 0.729 & 6.8 \\
\hline FeO-ZEO & 288 & 3.9 & $2.83 \mathrm{E}-08$ & 0.985 & 4.2 \\
FeO-ZEO & 298 & 3.8 & $1.81 \mathrm{E}-08$ & 0.850 & 5.3 \\
FeO-ZEO & 313 & 6.6 & $1.81 \mathrm{E}-08$ & 0.815 & 5.3 \\
\hline
\end{tabular}



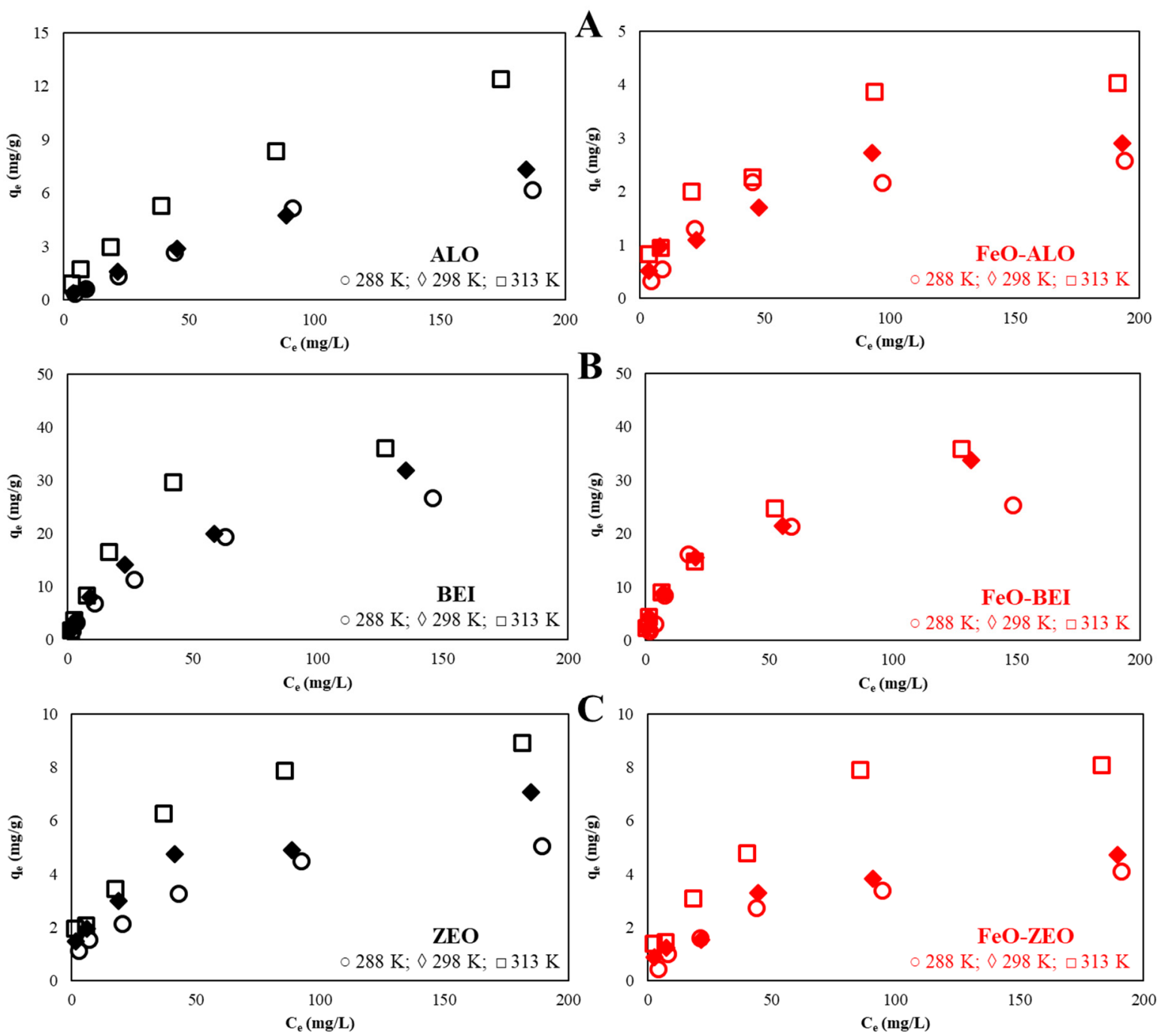

Figure 9. Adsorption isotherms (operational conditions: $283-313 \mathrm{~K}, \mathrm{pH}$ 6.0, adsorbate/adsorbent ratio: 500:1, 5-200 mg/L Ba) for natural and FeO-modified ALO (A), BEI (B) and ZEO (C). Symbols are larger than the analytical uncertainty.

An increase in temperature from 288 to $313 \mathrm{~K}$ resulted in a higher retention of $\mathrm{Ba}^{2+}$ ions. This dependency on temperature may be attributable to an increase of both the active surface sites and pore sizes of the adsorbents [50]. However, after a certain temperature limit is reached, the absorption capacity will start to decrease, which is at app. $318 \mathrm{~K}$ or higher for most silicate-based adsorbents [51].

The maximum monolayer adsorption capacities are $9.8 \mathrm{mg} / \mathrm{g}$ for ZEO, $16.8 \mathrm{mg} / \mathrm{g}$ for ALO and $44.8 \mathrm{mg} / \mathrm{g}$ for BEI and $9.6 \mathrm{mg} / \mathrm{g}$ for FeO-ZEO, $4.6 \mathrm{mg} / \mathrm{g}$ for FeO-ALO and $38.6 \mathrm{mg} / \mathrm{g}$ for FeO-BEI, respectively, at near-optimum temperature $(313 \mathrm{~K})$, which shows that the natural materials were in general advantageous over the FeO-modified ones. The calculated values for $\mathrm{E}(\mathrm{E}<8 \mathrm{~kJ} / \mathrm{mol})$ indicate that the $\mathrm{Ba}^{2+}$ uptake from solution follows physical adsorption rather than chemical ion exchange (e.g., [52-54]).

As expected, the adsorption of $\mathrm{Ba}^{2+}$ ions depended in particular on the type and on the related physicochemical properties of the natural and FeO-modified adsorbents, as indicated by our data (see Figure 9). This result is in line with the observations prior discussed elsewhere $[13,20,55]$. Apart from that the removal mechanisms for $\mathrm{Ba}^{2+}$ ions from solution by the different adsorbents may be much more complex than indicated by the adsorption isotherms for the reasons discussed in detail in Section 3.3.9. 


\subsubsection{Thermodynamics}

Thermodynamic parameters, such as Gibbs free energy $\left(\Delta \mathrm{G}^{0}\right)$, enthalpy $\left(\Delta \mathrm{H}^{0}\right)$ and entropy $\left(\Delta \mathrm{S}^{0}\right)$, were calculated in order to constrain the feasibility and the nature of the adsorption process (e.g., physical and chemical), according to Equations (9)-(12):

$$
\begin{aligned}
\Delta \mathrm{G}^{0} & =-\mathrm{R} \cdot \mathrm{T} \cdot \ln \mathrm{K}_{\mathrm{C}} \\
\Delta \mathrm{G}^{0} & =\Delta \mathrm{H}^{0}-\mathrm{T} \cdot \Delta \mathrm{S}^{0} \\
\ln \mathrm{K}_{\mathrm{C}} & =-\frac{\Delta \mathrm{H}^{0}}{\mathrm{RT}} \cdot \frac{1}{\mathrm{~T}}+\frac{\Delta \mathrm{S}^{0}}{\mathrm{R}} \\
\mathrm{K}_{\mathrm{C}} & =\mathrm{K}_{\mathrm{L}} \cdot 55.5 \cdot 1000
\end{aligned}
$$

where $\mathrm{K}_{\mathrm{L}}$ is the Langmuir constant (see Table 4; multiplied with the molecular weight of $\mathrm{Ba}(137.33 \mathrm{~g} / \mathrm{mol})$ to obtain the unit of $\mathrm{L} / \mathrm{mmol}$ ). $\mathrm{K}_{\mathrm{C}}$ is the equilibrium constant (dimensionless), which is obtained by the multiplication of $\mathrm{K}_{\mathrm{L}}$ with the factor of 55.5 (e.g., number of moles of pure water per liter), and then by

\begin{tabular}{|c|c|c|c|c|c|}
\hline \multirow[b]{2}{*}{ Adsorbent } & \multicolumn{3}{|c|}{$\Delta \mathrm{G}^{0}(\mathrm{~kJ} / \mathrm{mol})$} & \multirow[t]{2}{*}{$\Delta \mathrm{H}^{0}(\mathrm{~kJ} / \mathrm{mol})$} & \multirow[t]{2}{*}{$\Delta S^{0}(\mathrm{~kJ} / \mathrm{mol} \cdot \mathrm{K})$} \\
\hline & $288 \mathrm{~K}$ & $298 \mathrm{~K}$ & $313 \mathrm{~K}$ & & \\
\hline ALO & -25.69 & -26.97 & -30.13 & 3.13 & 0.022 \\
\hline FeO-ALO & -29.63 & -30.73 & -32.59 & 0.54 & 0.014 \\
\hline BEI & -29.11 & -30.49 & -32.44 & 1.10 & 0.016 \\
\hline FeO-BEI & -30.46 & -32.07 & -33.83 & 0.96 & 0.016 \\
\hline ZEO & -30.46 & -31.60 & -33.49 & 0.54 & 0.015 \\
\hline FeO-ZEO & -29.20 & -30.74 & -32.36 & 0.82 & 0.015 \\
\hline
\end{tabular}
1000 [40]. The values for $\Delta \mathrm{G}^{0}, \Delta \mathrm{H}^{0}$ and $\Delta \mathrm{S}^{0}$ are reported in Table 6.

Table 6. Summary of thermodynamic parameters: Gibbs free energy, enthalpy and entropy for the adsorption of aqueous $\mathrm{Ba}^{2+}$ by ALO, BEI and ZEO with(out) FeO-modification.

The $\Delta \mathrm{G}$ values suggest that the adsorption of $\mathrm{Ba}^{2+}$ by all adsorbent materials with (out) FeO-modification is feasible, spontaneous and more favorable at a higher temperature. The positive values obtained for $\Delta \mathrm{H}$ indicate the adsorption process to be endothermic. Positive $\Delta S$ values suggest an increase in randomness of the adsorption as temperature increases. Similar observations have been made by, e.g., Adeyemo et al. [56] and Uddin [57] and references therein.

\subsubsection{Regenerability}

The efficiency, including both sustainability and economic factors, of an adsorption is greatly increased, when (i) the adsorbed pollutant is recoverable via desorption and (ii) the adsorbent is regenerable, i.e., reuse is possible over multiple adsorption-desorption cycles. The amount of $\mathrm{Ba}^{2+}$ recovered at the end of each adsorption-desorption cycle (5 in total) is displayed as the desorption efficiency (DE\%) in Figure 10 and was calculated with the Equation (13):

$$
\mathrm{DE} \%=\frac{\text { Mass of sorbed } \mathrm{Ba}(m g) \text { at run }(n+1)}{\text { Mass of sorbed } B a(m g) \text { at run }(n)} \cdot 100
$$

It is evident that the desorption efficiencies of FeO-BEI and BEI remained above $80 \%$ and $70 \%$ after up to 5 consecutive cycles, which indicates that these adsorbents were neither severely damaged nor chemically modified during the multiple adsorption-desorption cycles, and that their reuse is possible. This is consistent with the mineralogical evaluation of FeO-BEI and BEI obtained after the $\mathrm{Ba}^{2+}$ adsorption (Supplementary Material Figures S1 and S2). A similar high regenerability was found for the bentonite-thiourea-formaldehyde composite after $\mathrm{Pb}^{2+}, \mathrm{Mn}^{7+}$ and $\mathrm{Cr}^{6+}$ sorption [54]. In contrast, 
the desorption efficiency of ALO and FeO-ALO was generally lower (40-50\%) compared to BEI and $\mathrm{FeO}-\mathrm{BEI}$ and decreased after 4 cycles, which suggests that the physical and surface charge properties the of these materials are modified under acidic conditions, and that their regenerability is limited. However, mineralogical changes have not been observed for the ALO-based adsorbents upon the regenerability test (Supplementary Material Figures S1 and S2). ZEO and FeO-ZEO displayed by far the lowest regenerability among all adsorbents tested in this study $(30 \%)$, which decreased dramatically to $5-10 \%$ after 5 cycles. FTIR spectra of the both adsorbents revealed intense structural modifications after the multiple adsorption-desorption cycles, making a reuse impossible (Supplementary Material Figure S2).
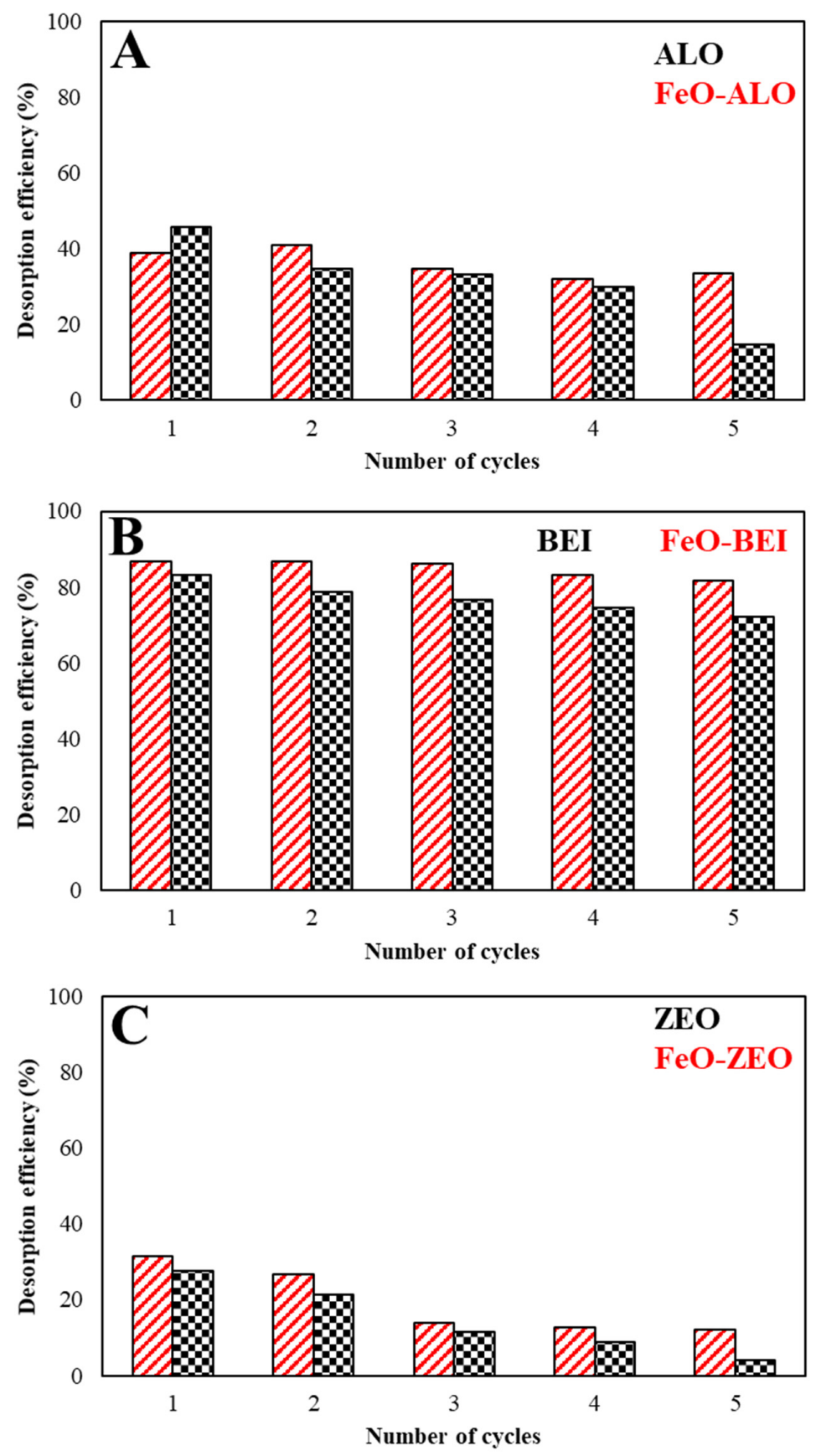

Figure 10. Regenerability (operational conditions: 298 K, pH 6.0-3.0, adsorbate/adsorbent ratio: 500:1, $10 \mathrm{mg} / \mathrm{L} \mathrm{Ba}$ ) of natural and FeO-modified ALO (A), BEI (B) and ZEO (C). 


\subsubsection{Uptake Mechanism(s)}

Habib and Bockris [58] have stated that the adsorption of an ionic species is unlikely to occur alone, because the developing solid-liquid interface must always be electrically neutral, meaning that there is either ion exchange on the surface or within the pore structure of a certain adsorbent or there might be a counterion in the diffuse layer of a certain adsorbent. Therefore, both the physicochemical properties of the adsorbate (ion radius, charge, ionic potential, electronegativity, hydration state, etc.) and the crystal-chemical parameters of the adsorbent (crystal structure, surface area, cation exchange capacity, etc.) are considered to play a significant role in controlling the direction and the magnitude of a certain adsorption and/or diffusion process. With respect to the adsorbents used in this study, one can conclude (simply speaking) that beidellite is a layered material with an expandable interlayer [15], allophane is an amorphous substance with a hollow "nanoball" structure that is intermitted by defect sites, the so-called perforations [17] and zeolite (natrolite and stilbite) is a crystalline material with a uniform three-dimensional pore structure [5].

The BEI-based adsorbents can expand in water, contrary to the ALO- and ZEO-based materials, making BEI and FeO-BEI more accessible for cations, which explains the high sorption capacities for $\mathrm{Ba}^{2+}$ ions $(44.8 \mathrm{mg} / \mathrm{g}$ and $38.6 \mathrm{mg} / \mathrm{g}$ at $313 \mathrm{~K})$. As for the competitive cation test, adsorption-desorption of ionic species on the charged surface as well as intercalation reactions in the interlayer are thought to have caused the release of $\mathrm{Na}^{+}$and $\mathrm{Mg}^{2+}$ to the solution and the simultaneous uptake of $\mathrm{Ba}^{2+}, \mathrm{K}^{+}$and $\mathrm{Ca}^{2+}$ ions onto the surface and within the layered structure of BEI and FeO-BEI, balancing charge and keeping electrical neutrality $[15,58]$. This assertion may be supported by the element distribution maps of BEI and FeO-BEI, shown in Figure 11, which have been collected after the adsorption. The $\mathrm{Al}$ and $\mathrm{Si}$ distributions belong to octahedral and tetrahedral sites, Fe occupies octahedral sites in beidellite as well as in goethite and hematite due to the FeO-modification, and $\mathrm{Ba}$ is the species sorbed onto the surface and/or within the interlayer of beidellite. Note that all elements are homogenously distributed across the sample, which indicates that sorption processes govern mainly the uptake of $\mathrm{Ba}^{2+}$ from solution, which is consistent with the interpretation of both the kinetics and adsorption isotherms. These sorption processes are reversible to a high degree, as indicated by the regenerability test (Figure 10).

In the case of ALO and FeO-ALO, it is suggested that $\mathrm{Na}^{+}$ions were liberated from and $\mathrm{Ba}^{2+}$ ions were attached onto the defect structural sites and external areas of the allophane nanoball structure. Inner-sphere complexation, formation of molecular clusters of hydrated Ba-complexes within the perforations and real intercalation processes are unlikely to occur, which could be a limiting factor for Ba sorption by allophane-based materials. This interpretation is in line with the conclusions drawn in other adsorption studies [13] and match the results obtained from molecular dynamics calculations of hydrated allophane [59].

ZEO is composed of natrolite and stilbite, which are structures with $8 \mathrm{MR}(2.6 \AA \times 3.9 \AA)$ and $9 \mathrm{MR}$ $(2.5 \AA \times 4.1 \AA)$ vs. $8 \mathrm{MR}(2.7 \AA \times 5.6 \AA)$ and $10 \mathrm{MR}(4.7 \AA \times 5.0 \AA)$ pores, respectively [60]. In other words, both zeolite minerals are characterized by small pores, whereby stilbite has a larger porous size than natrolite, but it is present in low quantity ( $26 \mathrm{wt} \% \mathrm{vs} .74 \mathrm{wt} \%$ ) in the adsorbent. The ionic radii of $\mathrm{Ba}^{2+}$ and of hydrated $\mathrm{Ba}^{2+}$ are about $1.4 \AA$ and $4.1 \AA$, respectively [61]. Thus, $\mathrm{Ba}^{2+}$ can enter inside the surface-related micropores of the zeolite minerals, but it barely fits into the internal pores due to its large hydration sphere, which explains the sluggish kinetics (Figure $5 \mathrm{c}$ ), the comparable low release of $\mathrm{Na}^{+}$as the counterion (i.e., compensating the negative charge arising from $\mathrm{Al}$ of the framework, cf. Figure 8 ) and the significantly lower sorption capacity of both ZEO and FeO-ZEO compared with the other absorbents (Table 4).

\subsubsection{Cost Factor}

Activated carbon components are the most frequently used adsorbents of our time. However, their applicability in wastewater treatment is restricted due to a limited regenerability, high costs in the order of US \$20-22,000 per ton and increasing difficulties arising from waste production and waste management after their operational use [62]. The results obtained in this study indicate that 
$\mathrm{BEI}$ and subordinate ALO and ZEO with(out) FeO-modification have a high affinity to bind $\mathrm{Ba}^{2+}$ ions over a wide $\mathrm{pH}$ range. Estimated mining costs for ALO are US \$200-600 per ton, which is higher than other economic smectite-clay deposits, such as the Wyoming bentonite and beidellite clays (US \$30-300 per ton), but significantly lower than low- to high purify zeolites (US \$300-20,000 per ton; [13]). The FeO-modification process, if required to increase the regenerability of a certain adsorbent, may increase the price per ton by $<10-20 \%$. The application of alternating layers of natural and FeO-modified BEI and other low-cost adsorbents in filter systems for wastewater treatment could be considered for a better cost-effectiveness.
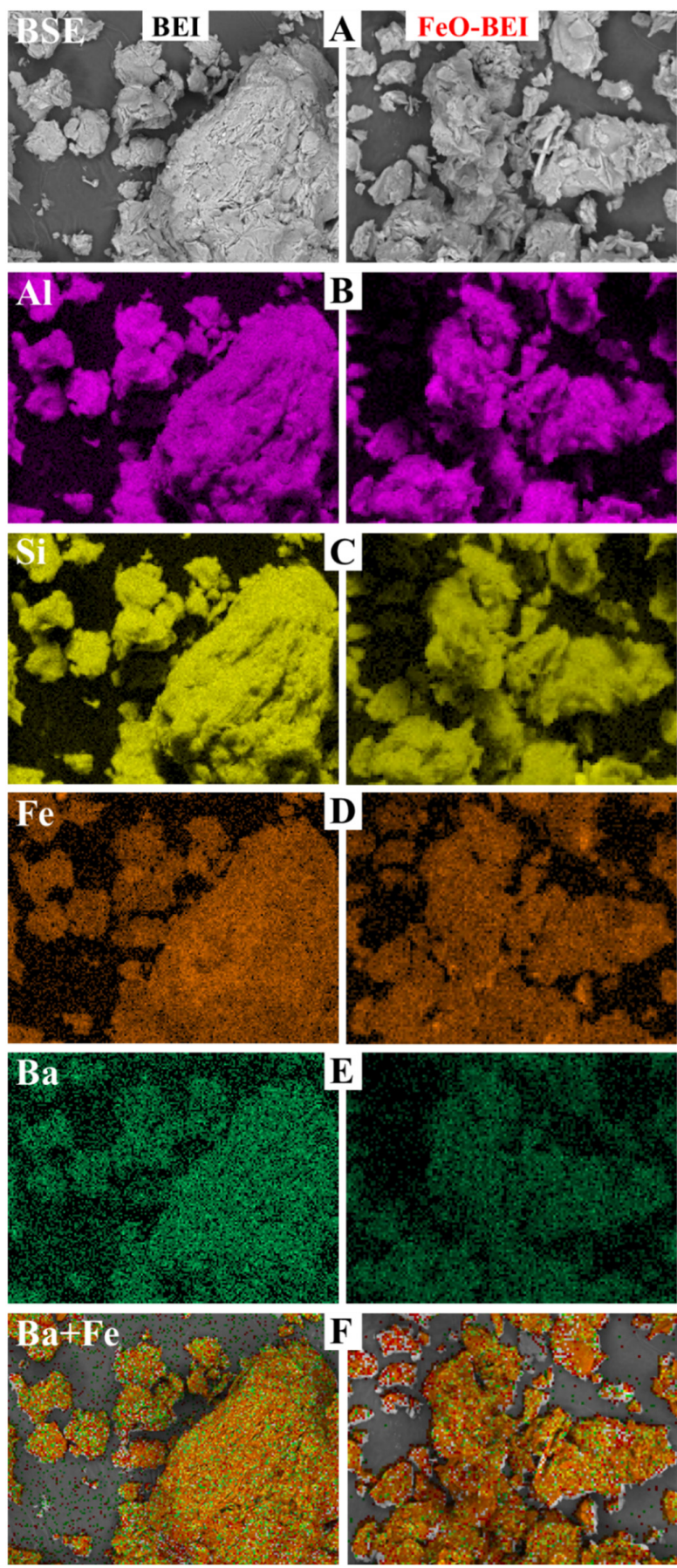

Figure 11. Backscattered electron images (A), distribution maps of $\mathrm{Al}(\mathbf{B}), \mathrm{Si}(\mathbf{C}), \mathrm{Fe}(\mathbf{D})$ and $\mathrm{Ba}(\mathbf{E})$ and overlay maps (F) of Ba (green) + Fe (orange) of BEI and FeO-BEI. Image width: all $15 \mu \mathrm{m}$. 


\subsection{Comparison of Adsorbents}

Table 7 shows a comparison between the adsorption capacities for aqueous $\mathrm{Ba}^{2+}$ obtained in this study and those reported in previous studies using similar and other adsorbents. It can be seen that ALO, BEI and ZEO with and without FeO-modification are comparable to most other adsorbents, although such an evaluation may be erroneous for the reasons discussed in De Gisi et al. [62].

Table 7. Comparison of the adsorption capacities of various materials for the adsorption of $\mathrm{Ba}^{2+}$ from solution under different operational conditions. TS-this study.

\begin{tabular}{|c|c|c|c|c|c|c|c|}
\hline & $\mathrm{Q}_{\text {max }}^{0}$ & Surface Area/ & Conc. Range & Equil. Time & $\mathbf{T}$ & (Optimu & \\
\hline Adsorbent & $(\mathrm{mg} / \mathrm{g})$ & Particle Size & of Pollutant & (h) & $\left({ }^{\circ} \mathrm{C}\right)$ & PH & Reference \\
\hline Alk- $\mathrm{Ti}_{3} \mathrm{C}_{2} \mathrm{~T}_{\mathrm{x}}$ & 46.5 & $76.4 \mathrm{~m}^{2} / \mathrm{g}$ & $50-500 \mathrm{mg} / \mathrm{L}$ & 24 & RT & $7.0-10.0$ & [63] \\
\hline Aloe Vera biosorbent & 107.5 & $<125 \mu \mathrm{m}$ & $5-200 \mathrm{mg} / \mathrm{L}$ & 1 & 20 & 5.0 & [64] \\
\hline Ash (thermal power plant) & 15.1 & $7 \mathrm{~m}^{2} / \mathrm{g}$ & $50-1000 \mathrm{mg} / \mathrm{L}$ & 0.5 & 50 & $4.0-5.0$ & [65] \\
\hline Ca-clinoptilolite & 15.3 & $<75 \mu \mathrm{m}$ & $0.005-0.1 \mathrm{~N}$ & 168 & RT & - & [20] \\
\hline Ca-montmorillonite & 15.3 & $<75 \mu \mathrm{m}$ & $0.005-0.1 \mathrm{~N}$ & 48 & RT & - & [20] \\
\hline Chromium(IV) oxide & 0.1 & $100-150 \mu \mathrm{m}$ & $0.01-1370 \mathrm{mg} / \mathrm{L}$ & 1.5 & 60 & 11.4 & [66] \\
\hline Dolomite & 4.0 & $20 \mu \mathrm{m}$ & $10-50 \mathrm{mg} / \mathrm{L}$ & 2 & 20 & 5.5 & [24] \\
\hline Hydrous ceric oxide & 0.1 & $120 \mu \mathrm{m}$ & $0.01-1370 \mathrm{mg} / \mathrm{L}$ & 1 & 60 & 11.4 & [67] \\
\hline Expanded perlite & 2.5 & $20 \mu \mathrm{m}$ & $5-50 \mathrm{mg} / \mathrm{L}$ & 1.5 & 20 & 6.0 & [68] \\
\hline Kaolinite & 14.8 & $<38 \mu \mathrm{m}$ & $0.002-214 \mathrm{mg} / \mathrm{L}$ & 288 & $\mathrm{RT}$ & $>8.0$ & [19] \\
\hline Mixed chlorite-illite & 16.7 & $<38 \mu \mathrm{m}$ & $0.002-214 \mathrm{mg} / \mathrm{L}$ & 144 & RT & $>8.0$ & [19] \\
\hline MOF-based Ba traps & 131.1 & $0.4 \mathrm{~m}^{2} / \mathrm{g}$ & $10-1000 \mathrm{mg} / \mathrm{L}$ & 0.1 & 25 & 5.8 & [26] \\
\hline Montmorillonite & 20.8 & $<38 \mu \mathrm{m}$ & $0.002-214 \mathrm{mg} / \mathrm{L}$ & 192 & RT & $>8.0$ & [19] \\
\hline $\mathrm{Ti}_{3} \mathrm{C}_{2} \mathrm{~T}_{\mathrm{x}}$ Mxene & 175.1 & $10 \mathrm{~m}^{2} / \mathrm{g}$ & $0.2-10 \mathrm{~g} / \mathrm{L}$ & 1 & 40 & $7.0-9.0$ & [50] \\
\hline Natural allophane & 10.6 & $294 \mathrm{~m}^{2} / \mathrm{g}$ & $1-100 \mathrm{mg} / \mathrm{L}$ & 0.2 & 25 & 8.5 & [13] \\
\hline Natural clinoptilolite & 41.1 & $224-500 \mu \mathrm{m}$ & $0.1 \mathrm{~N}$ & 72 & 25 & - & [69] \\
\hline Na-clinoptilolite & 109.6 & $224-500 \mu \mathrm{m}$ & $0.1 \mathrm{~N}$ & 73 & 26 & - & [69] \\
\hline Nano-polymer SAB & 57.7 & $4.3 \mathrm{~m}^{2} / \mathrm{g}$ & $10-500 \mathrm{mg} / \mathrm{L}$ & 8 & 20 & 8.0 & [70] \\
\hline Nano-polymer SASB & 210.4 & $5.9 \mathrm{~m}^{2} / \mathrm{g}$ & $10-500 \mathrm{mg} / \mathrm{L}$ & 6 & 20 & 8.0 & [70] \\
\hline Nanoscale zero valent iron & 22.6 & $20-100 \mathrm{~nm}$ & $0.1-137 \mathrm{mg} / \mathrm{L}$ & 4 & 25 & - & [42] \\
\hline Pecan shell act. carbon & 3.3 & $0.4 \mathrm{~m}^{2} / \mathrm{g}$ & $25-100 \mathrm{mg} / \mathrm{L}$ & 0.5 & 70 & $6.0-10.0$ & [71] \\
\hline Synthetic allophane-1 & 38.6 & $358 \mathrm{~m}^{2} / \mathrm{g}$ & $1-100 \mathrm{mg} / \mathrm{L}$ & 0.2 & 25 & 8.5 & [13] \\
\hline Synthetic allophane-2 & 17.2 & $370 \mathrm{~m}^{2} / \mathrm{g}$ & $1-100 \mathrm{mg} / \mathrm{L}$ & 0.2 & 25 & 8.5 & [13] \\
\hline $\mathrm{Ti}_{3} \mathrm{C}_{2} \mathrm{~T}_{\mathrm{x}}$ & 12.0 & $9.8 \mathrm{~m}^{2} / \mathrm{g}$ & $50-500 \mathrm{mg} / \mathrm{L}$ & 24 & RT & $7.0-10.0$ & [63] \\
\hline Zeolite-rich tuff & 230.2 & $0.3-0.6 \mathrm{~mm}$ & $50-500 \mathrm{mg} / \mathrm{L}$ & 0.5 & 22 & 7.7 & [25] \\
\hline Zeolite Z70-4 & 17.0 & $25 \mathrm{~m}^{2} / \mathrm{g}$ & $50-1000 \mathrm{mg} / \mathrm{L}$ & 0.5 & 50 & $4.0-5.0$ & [65] \\
\hline Zeolite Z90-4 & 119.0 & $40 \mathrm{~m}^{2} / \mathrm{g}$ & $50-1000 \mathrm{mg} / \mathrm{L}$ & 0.5 & 50 & $4.0-5.0$ & [65] \\
\hline Zeolite Z90-15 & 117.7 & $122 \mathrm{~m}^{2} / \mathrm{g}$ & $50-1000 \mathrm{mg} / \mathrm{L}$ & 0.5 & 50 & $4.0-5.0$ & [65] \\
\hline ALO & 16.8 & $368.5 \mathrm{~m}^{2} / \mathrm{g}$ & $5-200 \mathrm{mg} / \mathrm{L}$ & 0.2 & 40 & $7.5-8.5$ & TS \\
\hline FeO-ALO & 4.6 & $342.1 \mathrm{~m}^{2} / \mathrm{g}$ & $5-200 \mathrm{mg} / \mathrm{L}$ & 0.1 & 40 & $7.5-8.5$ & TS \\
\hline BEI & 44.8 & $50.3 \mathrm{~m}^{2} / \mathrm{g}$ & $5-200 \mathrm{mg} / \mathrm{L}$ & 0.2 & 40 & $7.5-8.5$ & TS \\
\hline FeO-BEI & 38.6 & $50.1 \mathrm{~m}^{2} / \mathrm{g}$ & $5-200 \mathrm{mg} / \mathrm{L}$ & 0.1 & 40 & $7.5-8.5$ & TS \\
\hline ZEO & 9.8 & $2.3 \mathrm{~m}^{2} / \mathrm{g}$ & $5-200 \mathrm{mg} / \mathrm{L}$ & 0.5 & 40 & $7.5-8.5$ & TS \\
\hline FeO-ZEO & 9.6 & $2.6 \mathrm{~m}^{2} / \mathrm{g}$ & $5-200 \mathrm{mg} / \mathrm{L}$ & 0.5 & 40 & $7.5-8.5$ & TS \\
\hline
\end{tabular}

The materials tested in this study were not among the highest available, such as $\mathrm{Ti}_{3} \mathrm{C}_{2} \mathrm{~T}_{\mathrm{x}}$ Mxene [50], functionalized polymer (SASB-type) nanoparticles [70], phillipsite-chabazite-rich tuff [25] and synthetic zeolites [65]. However, comparably high uptake capacities for aqueous $\mathrm{Ba}^{2+}$ by BEI and FeO-BEI were obtained, compared to, for example, dolomite [24], expended perlite [68], (hydrous) metal oxides [66,67], other clay minerals $[19,20]$, nanoscale zero valent iron [42] and pecan shell-based activated carbon [71].

Indeed, $\mathrm{BEI}$ and, to a lesser extent, FeO-BEI exhibited a superior efficiency to adsorb $\mathrm{Ba}^{2+}$ ions over a broad $\mathrm{pH}$ range ( $\mathrm{pH} 4.5-8.5)$ and both materials showed a high regenerability (70-80\%) even after five adsorption-desorption cycles. Furthermore, the expected low price and the worldwide occurrence make especially $\mathrm{BEI}$ an interesting candidate material for $\mathrm{Ba}^{2+}$ removal from solution; yet, its performance in large-scale applications has to be proven. 


\section{Conclusions}

The adsorption behavior of aqueous $\mathrm{Ba}^{2+}$ by natural and $\mathrm{FeO}$-modified allophane (ALO and FeO-ALO), beidellite (BEI and FeO-BEI) and zeolite (ZEO and FeO-ZEO) was analyzed in kinetic and equilibrium experiments as a function of different operating parameters, such as contact time, $\mathrm{pH}$, initial $\mathrm{Ba}^{2+}$ concentration, temperature, presence of competing cations and adsorbent dosage. The results obtained from the kinetic studies indicate that the adsorption of $\mathrm{Ba}^{2+}$ was completed within 5-30 min and followed the pseudo-first-order reaction model. Ideal $\mathrm{pH}$ and temperature conditions for $\mathrm{Ba}^{2+}$ removal from solution were $\mathrm{pH} 7.5-8.0$ and $313 \mathrm{~K}$ for all adsorbents. The adsorption data fitted to the Langmuir isotherm model, yielding maximum adsorption capacities for BEI $(44.8 \mathrm{mg} / \mathrm{g})$ and FeO-BEI $(38.6 \mathrm{mg} / \mathrm{g})$, relative to the other ALO- and ZEO-based adsorbents $(3.0-16.8 \mathrm{mg} / \mathrm{g})$. The adsorption process is mainly based on physical adsorption and follows in the order: $\mathrm{Ba}^{2+}>\mathrm{K}^{+}$ $>\mathrm{Ca}^{2+}>>\mathrm{Mg}^{2+}$ for all adsorbents. The results of this study show that BEI and FeO-BEI are useful adsorbents for the removal of $\mathrm{Ba}^{2+}$ from aqueous solution.

Supplementary Materials: The following are available online at http://www.mdpi.com/1996-1944/13/11/2582/s1, Figure S1: XRD patterns of adsorbents collected after the Ba adsorption, Figure S2: FTIR spectra of adsorbents collected after the Ba adsorption, Figure S3: EDX spectra obtained from single spot analyses (areas are marked in Figure 4).

Author Contributions: Conceptualization, data curation, formal analysis and project administration: A.B.; investigation and methodology: A.B., Y.F., S.S., K.W., M.N. and S.E. All authors contributed to the writing of the original draft. All authors have read and agreed to the published version of the manuscript.

Funding: This research was funded by the NAWI Graz Geocenter (Graz University of Technology), the BMBWF project “HRSM_Projekt ELMINet Graz" and the ACR Strategisches Projektprogramm 2016 “Innovative Materialcharakterisierung (SP2016-002-006)".

Acknowledgments: The authors are grateful to M. Hierz, J. Jernej, S. Perchthold and A. Wolf (Graz University of Technology), who assisted us with the synthesis and the adsorption experiments. F. Steindl (Graz University of Technology) is acknowledged for providing the BET data. H. Schroettner and J. Rattenberger (Graz Centre for Electron Microscopy and Graz University of Technology) are acknowledged of providing SEM infrastructure access.

Conflicts of Interest: We declare no conflict of interests.

\section{References}

1. Bacquart, T.; Frisbie, S.; Mitchell, E.; Grigg, L.; Cole, C.; Small, C.; Sarkar, B. Multiple inorganic toxic substances contaminating the groundwater of Myingyan Township, Myanmar: Arsenic, manganese, fluoride, iron, and uranium. Sci. Total. Environ. 2015, 517, 232-245. [CrossRef] [PubMed]

2. Malik, Q.A.; Khan, M.S. Effect on Human Health due to Drinking Water Contaminated with Heavy Metals. J. Pollut. Eff. Cont. 2016, 5, 1000179.

3. Chabukdhara, M.; Gupta, S.K.; Kotecha, Y.; Nema, A.K. Groundwater quality in Ghaziabad district, Uttar Pradesh, India: Multivariate and health risk assessment. Chemosphere 2017, 179, 167-178. [CrossRef] [PubMed]

4. Baldermann, A.; Landler, A.; Mittermayr, F.; Letofsky-Papst, I.; Steindl, F.; Galan, I.; Dietzel, M. Removal of heavy metals (Co, Cr, and $\mathrm{Zn}$ ) during calcium-aluminium-silicate-hydrate and trioctahedral smectite formation. J. Mater. Sci. 2019, 54, 9331-9351. [CrossRef]

5. Araissi, M.; Ayed, I.; Elaloui, E.; Moussaoui, Y. Removal of barium and strontium from aqueous solution using zeolite 4A. Water Sci. Technol. 2016, 77, 1628-1636. [CrossRef]

6. Dhingra, N.; Singh, N.S.; Parween, T.; Sharma, R. Heavy Metal Remediation by Natural Adsorbents. In Modern Age Waste Water Problems; Oves, M., Ansari, M., Zain Khan, M., Shahadat, M., M.I. Ismail, I., Eds.; Springer: Cham, Switzerland, 2020.

7. Fu, F.; Wang, Q. Removal of heavy metal ions from wastewaters: A review. J. Environ. Manag. 2011, 92, 407-418. [CrossRef]

8. Carolin, C.F.; Kumar, P.S.; Saravanan, A.; Joshiba, G.J.; Naushad, M. Efficient techniques for the removal of toxic heavy metals from aquatic environment: A review. J. Environ. Chem. Eng. 2017, 5, 2782-2799. [CrossRef] 
9. Babel, S.; Kurniawan, T.A. Low-cost adsorbents for heavy metals uptake from contaminated water: A review. J. Hazard. Mater. 2003, B97, 219-243. [CrossRef]

10. Mukai, H.; Hirose, A.; Motai, S.; Kikuchi, R.; Tanoi, K.; Nakanishi, T.M.; Yaita, T.; Kogure, T. Cesium adsorption/desorption behavior of clay minerals considering actual contamination conditions in Fukushima. Sci. Rep. 2016, 6, 21543. [CrossRef]

11. Mukhopadhyay, R.; Bhaduri, D.; Sarkar, B.; Rusmin, R.; Hou, D.; Khanam, R.; Sarkar, S.; Biswas, J.K.; Vithanage, M.; Bhatnagar, A.; et al. Clay-polymer nanocomposites: Progress and challenges for use in sustainable water treatment. J. Hazard. Mater. 2020, 383, 121125. [CrossRef]

12. Baldermann, A.; Warr, L.N.; Letofsky-Papst, I.; Mavromatis, V. Substantial iron sequestration during green-clay authigenesis in modern deep-sea sediments. Nat. Geosci. 2015, 8, 885-889. [CrossRef]

13. Baldermann, A.; Grießbacher, A.C.; Baldermann, C.; Purgstaller, B.; Letofsky-Papst, I.; Kaufhold, S.; Dietzel, M. Removal of barium, cobalt, strontium, and zinc from solution by natural and synthetic allophane adsorbents. Geosciences 2018, 8, 309. [CrossRef]

14. Abu-Danso, E.; Peräniemi, S.; Leiviskä, T.; Kim, T.Y.; Tripathi, K.M.; Bhatnagar, A. Synthesis of clay-cellulose biocomposite for the removal of toxic metal ions from aqueous medium. J. Hazard. Mater. 2020, 381, 120871. [CrossRef] [PubMed]

15. Kakaei, S.; Khameneh, E.S.; Rezazadeh, F.; Hosseini, M.H. Heavy metal removing by modified bentonite and study of catalytic activity. J. Mol. Struct. 2020, 1199, 126989. [CrossRef]

16. Clark, C.J.; McBride, M.B. Chemisorption of $\mathrm{Cu}(\mathrm{II})$ and $\mathrm{Co}(\mathrm{II})$ on allophane and imogolite. Clays Clay Miner. 1984, 32, 300-310. [CrossRef]

17. Parfitt, R.L. Allophane in New Zealand-A review. Aust. J. Soil Res. 1990, 28, 343-360. [CrossRef]

18. Wu, Y.; Lee, C.-P.; Mimura, H.; Zhang, X.; Wei, Y. Stable solidification of silica-based ammonium molybdophosphate by allophane: Application to treatment of radioactive cesium in secondary solid wastes generated from fukushima. J. Hazard. Mater. 2018, 341, 46-54. [CrossRef]

19. Eylem, C.; Erten, H.N.; Görktürk, H. Sorption-Desorption Behaviour of Barium on Clays. J. Environ. Radioactivity 1990, 11, 183-200. [CrossRef]

20. Chávez, M.L.; de Pablo, L.; García, T.A. Adsorption of $\mathrm{Ba}^{2+}$ by Ca-exchange clinoptilolite tuff and montmorillonite clay. J. Hazard. Mater. 2010, 175, 216-223. [CrossRef]

21. Purdey, M. Chronic barium intoxication disrupts sulphated proteoglycan synthesis: A hypothesis for the origins of multiple sclerosis. Med. Hypotheses 2004, 62, 746-754. [CrossRef]

22. Charbonnier, Q.; Moynier, F.; Bouchez, J. Barium isotope cosmochemistry and geochemistry. Sci. Bull. 2018, 63, 385-394. [CrossRef]

23. Baeza-Alvarado, M.D.; Olguín, M.T. Surfactant-modified clinoptilolite-rich tuff to remove barium $\left(\mathrm{Ba}^{2+}\right)$ and fulvic acid from mono- and bi-component aqueous media. Micropor. Mesopor. Mat. 2011, 139, 81-86. [CrossRef]

24. Ghaemi, A.; Torab-Mostaedi, M.; Ghannadi-Maragheh, M. Characterizations of strontium(II) and barium(II) adsorption from aqueous solutions using dolomite powder. J. Hazard. Mater. 2011, 190, 916-921. [CrossRef] [PubMed]

25. Pepe, F.; de Gennaro, B.; Aprea, P.; Caputo, D. Natural zeolites for heavy metals removal from aqueous solutions: Modeling of the fixed bed $\mathrm{Ba}^{2+} / \mathrm{Na}^{+}$ion-exchange process using a mixed phillipsite/chabazite-rich tuff. Chem. Eng. J. 2013, 219, 37-42. [CrossRef]

26. Peng, Y.; Huang, H.; Liu, D.; Zhong, C. Radioactive Barium Ion Trap Based on Metal-Organic Framework for Efficient and Irreversible Removal of Barium from Nuclear Wastewater. ACS Appl. Mater. Interfaces 2016, 8, 8527-8535. [CrossRef]

27. Nguyen, T.C.; Loganathan, P.; Nguyen, T.V.; Vigneswaran, S.; Kandasamy, J.; Naidu, R. Simultaneous adsorption of $\mathrm{Cd}, \mathrm{Cr}, \mathrm{Cu}, \mathrm{Pb}$, and $\mathrm{Zn}$ by an iron-coated Australian zeolite in batch and fixed-bed column studies. Chem. Eng. J. 2015, 270, 393-404. [CrossRef]

28. Baragaňo, D.; Alonso, J.; Gallego, J.R.; Lobo, M.C.; Gil-Díaz, M. Zero valent iron and goethite nanoparticles as new promising remediation techniques for As-polluted soils. Chemosphere 2020, 238, 124624. [CrossRef]

29. Parkhurst, D.L.; Appelo, C.A.J. Description of input and examples for PHREEQC version 3-A computer program for speciation, batch-reaction, one-dimensional transport, and inverse geochemical calculations. U.S. Geol. Surv. Tech. Methods 2013, 6, 497. 
30. Voigt, M.; Pearce, C.R.; Baldermann, A.; Oelkers, E.H. Stable and radiogenic strontium isotope fractionation during hydrothermal seawater-basalt interaction. Geochim. Cosmochim. Acta 2018, 240, 131-151. [CrossRef]

31. Baldermann, A.; Abdullayev, E.; Taghiyeva, Y.; Alasgarov, A.; Javad-Zada, Z. Sediment petrography, mineralogy and geochemistry of the Miocene Islam Dağ Section (Eastern Azerbaijan): Implications for the evolution of sediment provenance, palaeo-environment and (post-)depositional alteration patterns. Sedimentology 2020, 67, 152-172. [CrossRef]

32. Richoz, S.; Baldermann, A.; Frauwallner, A.; Harzhauser, M.; Daxner-Höck, G.; Klammer, D.; Piller, W.E. Geochemistry and mineralogy of the Oligo-Miocene sediments of the Valley of Lakes, Mongolia. Palaeobio. Palaeoenv. 2017, 97, 233-258. [CrossRef] [PubMed]

33. Mavromatis, V.; Immenhauser, A.; Buhl, D.; Purgstaller, B.; Baldermann, A.; Dietzel, M. Effect of organic ligands on $\mathrm{Mg}$ partitioning and $\mathrm{Mg}$ isotope fractionation during low-temperature precipitation of calcite in the absence of growth rate effects. Geochim. Cosmochim. Acta. 2017, 207, 139-153. [CrossRef]

34. Levard, C.; Doelsch, E.; Basile-Doelsch, I.; Abidin, Z.; Miche, H.; Masion, A.; Rose, J.; Borschneck, D.; Bottero, J.-Y. Structure and distribution of allophanes, imogolite and proto-imogolite in volcanic soils. Geoderma 2012, 183-184, 100-108. [CrossRef]

35. Baldermann, A.; Dohrmann, R.; Kaufhold, S.; Nickel, C.; Letofsky-Papst, I.; Dietzel, M. The Fe-Mg-saponite solid solution series-A hydrothermal synthesis study. Clay Miner. 2014, 49, 391-415. [CrossRef]

36. Roy, J.; Bandyopadhyay, N.; Das, S.; Maitra, S. Studies on the Formation of Mullite from Diphasic $\mathrm{Al}_{2} \mathrm{O}_{3}-\mathrm{SiO}_{2}$ Gel by Fourier Transform Infrared Spectroscopy. Iran. J. Chem. Chem. Eng. 2011, 30, 65-71.

37. Ma, Y.; Liu, Z.; Geng, A.; Vogt, T.; Lee, Y. Structural and spectroscopic studies of alkali-metal exchanged stilbites. Micropor. Mesopor. Mat. 2016, 224, 339-348. [CrossRef]

38. Burakov, A.E.; Galunin, E.V.; Burakova, I.V.; Kucherova, A.E.; Agarwal, S.; Tkachev, A.G.; Gupta, V.K. Adsorption of heavy metals on conventional and nanostructured materials for wastewater treatment purposes: A review. Ecotoxicol. Environ. Saf. 2018, 148, 702-712. [CrossRef]

39. Motsi, T.; Rowson, N.A.; Simmons, M.J.H. Adsorption of heavy metals from acid mine drainage by natural zeolite. Int. J. Miner. Process. 2009, 92, 42-48. [CrossRef]

40. Tran, H.N.; You, S.-J.; Hosseini-Bandegharaei, A.; Chao, H.-P. Mistakes and inconsistencies regarding adsorption of contaminants from aqueous solutions: A critical review. Wat. Res. 2017, 120, 88-116. [CrossRef]

41. Dzwigaj, S.; Massiani, P.; Davidson, A.; Che, M. Role of silanol groups in the incorporation of V in $\beta$ zeolite. J. Mol. Catal. A Chem. 2000, 155, 169-182. [CrossRef]

42. Çelebi, O.; Üzüm, Ç.; Shahwan, T.; Erten, H.N. A radiotracer study of the adsorption behavior of aqueous $\mathrm{Ba}^{2+}$ ions on nanoparticles of zero-valent iron. J. Hazard. Mater. 2007, 148, 761-767. [CrossRef] [PubMed]

43. Han, R.; Zou, W.; Wang, Y.; Zhu, L. Removal of uranium(VI) from aqueous solutions by manganese oxide coated zeolite: Discussion of adsorption isotherms and pH effect. J. Environ. Radioactivity 2007, 93, 127-143. [CrossRef] [PubMed]

44. De Sousa, D.N.R.; Insa, S.; Mozeto, A.A.; Petrovic, M.; Chaves, T.F.; Fadini, P.S. Equilibrium and kinetic studies of the adsorption of antibiotics from aqueous solutions onto powdered zeolites. Chemosphere 2018, 205, 137-146. [CrossRef] [PubMed]

45. Opiso, E.; Sato, T.; Yoneda, T. Adsorption and co-precipitation behavior of arsenate, chromate, selenate and boric acid with synthetic allophane-like materials. J. Hazard. Mater. 2009, 170, 79-86. [CrossRef] [PubMed]

46. Pawar, R.R.; Kim, M.; Kim, J.-G.; Hong, S.-M.; Sawant, S.Y.; Lee, S.M. Efficient removal of hazardous lead, cadmium, and arsenic from aqueous environment by iron oxide modified clay-activated carbon composite beads. Appl. Clay Sci. 2018, 162, 339-350. [CrossRef]

47. Najafabadi, H.H.; Irani, M.; Rad, L.R.; Haratameh, A.H.; Haririan, I. Removal of $\mathrm{Cu}^{2+}, \mathrm{Pb}^{2+}$ and $\mathrm{Cr}^{6+}$ from aqueous solutions using a chitosan/graphene oxide composite nanofibrous adsorbent. RSC Adv. 2015, 5, 16532. [CrossRef]

48. Amarasinghe, B.M.W.P.K.; Williams, R.A. Tea waste as a low cost adsorbent for the removal of $\mathrm{Cu}$ and $\mathrm{Pb}$ from wastewater. Chem. Eng. J. 2007, 132, 299-309. [CrossRef]

49. WHO. Barium in Drinking-Water; World Health Organization: Geneva, Switzerland, 2004.

50. Jun, B.-M.; Park, C.M.; Heo, J.; Yoon, Y. Adsorption of $\mathrm{Ba}^{2+}$ and $\mathrm{Sr}^{2+}$ on $\mathrm{Ti}_{3} \mathrm{C}_{2} \mathrm{~T}_{\mathrm{x}}$ MXene in model fracking wastewater. J. Environ. Manage. 2020, 256, 109940. [CrossRef] 
51. Mnasri-Ghnimi, S.; Frini-Srasra, N. Removal of heavy metals from aqueous solutions by adsorption using single and mixed pillared clays. Appl. Clay Sci. 2019, 179, 105151. [CrossRef]

52. Mahramanlioglu, M.; Kizilcikli, I.; Bicer, I.O. Adsorption of fluoride from aqueous solution by acid treated spent bleaching earth. J. Fluorine Chem. 2002, 115, 41-47. [CrossRef]

53. Singha, A.S.; Guleria, A. Chemical modification of cellulosic biopolymer and its use in removal of heavy metal ions from wastewater. Int. J. Biol. Macromol. 2014, 67, 409-417. [CrossRef] [PubMed]

54. El-Korashy, S.A.; Elwakeel, K.Z.; El-Hafeiz, A.A. Fabrication of bentonite/thiourea-formaldehyde composite material for $\mathrm{Pb}(\mathrm{II}), \mathrm{Mn}(\mathrm{VII})$ and $\mathrm{Cr}(\mathrm{VI})$ sorption: A combined basic study and industrial application. J. Clean. Prod. 2016, 137, 40-50. [CrossRef]

55. Sajih, M.; Bryan, N.D.; Livens, F.R.; Vaughan, D.J.; Descostes, M.; Phrommavanh, V.; Nos, J.; Morris, K. Adsorption of radium and barium on goethite and ferrihydrite: A kinetic and surface complexation modelling study. Geochim. Cosmochim. Acta 2014, 146, 150-163. [CrossRef]

56. Adeyemo, A.A.; Adeoye, I.O.; Bello, O.S. Adsorption of dyes using different types of clay: A review. Appl. Water Sci. 2017, 7, 543-568. [CrossRef]

57. Uddin, M.K. A review on the adsorption of heavy metals by clay minerals, with special focus on the past decade. Chem. Eng. J. 2017, 308, 438-462. [CrossRef]

58. Habib, M.A.; Bockris, J.O. Specific Adsorption of Ions. In Comprehensive Treatise of Electrochemistry; Bockris, J.O., Conway, B.E., Yeager, E., Eds.; Springer: Boston, MA, USA, 1980; pp. 135-219.

59. Creton, B.; Bougeard, D.; Smirnov, K.S.; Guilment, J.; Poncelet, O. Structural Model and Computer Modeling Study of Allophane. J. Phys. Chem. C 2008, 112, 358-364. [CrossRef]

60. Baerlocher, C.; McCusker, L.B.; Olsen, D.H. Atlas of Zeolite Framework Types, 6th ed.; Elsevier: Amsterdam, The Netherlands, 2007; pp. 1-308.

61. Dove, P.M.; Nix, C.J. The influence of the alkaline earth cations, magnesium, calcium, and barium on the dissolution kinetics of quartz. Geochim. Cosmochim. Acta 1997, 61, 3329-3340. [CrossRef]

62. De Gisi, S.; Lofrano, G.; Grassi, M.; Notarnicola, M. Characteristics and adsorption capacities of low-cost sorbents for wastewater treatment: A review. Sust. Mater. Technol. 2016, 9, 10-40. [CrossRef]

63. Mu, W.; Du, S.; Yu, Q.; Li, X.; Wei, H.; Yang, Y. Improving barium ion adsorption on two-dimensional titanium carbide by surface modification. Dalton Trans. 2018, 47, 8375-8381. [CrossRef]

64. Kapashi, E.; Kapnisti, M.; Dafnomili, A.; Noli, F. Aloe Vera as an effective biosorbent for the removal of thorium and barium from aqueous solutions. J. Radioanal. Nucl. Chem. 2019, 321, 217-226. [CrossRef]

65. Noli, F.; Kapnisti, M.; Buema, G.; Harja, M. Retention of barium and europium radionuclides from aqueous solutions on ash-based sorbents by application of radiochemical techniques. Appl. Radiat. Isot. 2016, 116, 102-109. [CrossRef] [PubMed]

66. Mishra, S.P.; Singh, V.K. Radiotracer Technique in Adsorption Study-XIII. Adsorption of Barium and Cesium Ions on Chromium(IV) Oxide Powder. Appl. Radiat. Isot. 1995, 46, 847-853. [CrossRef]

67. Mishra, S.P.; Singh, V.K. Radiotracer Technique in Adsorption Study-XI. Adsorption of Barium and Cesium Ions on Hydrous Ceric Oxide. Appl. Radiat. Isot. 1995, 46, 75-81. [CrossRef]

68. Torab-Mostaedi, M.; Ghaemi, A.; Ghassabzadeh, H.; Ghannadi-Maragheh, M. Removal of strontium and barium from aqueous solutions by adsorption onto expanded Perlite. Can. J Chem. Eng. 2011, 89, 1247-1254. [CrossRef]

69. Faghihian, H.; Marageh, M.G.; Kazemian, H. The use of clinoptilolite and its sodium form for removal of radioactive cesium, and strontium from nuclear wastewater and $\mathrm{Pb}^{2+}, \mathrm{Ni}^{2+}, \mathrm{Cd}^{2+}, \mathrm{Ba}^{2+}$ from municipal wastewater. Appl. Radiat. Isot. 1999, 50, 655-660. [CrossRef]

70. Younis, S.A.; Ghobashy, M.M.; Bassioni, G.; Gupta, A.K. Tailored functionalized polymer nanoparticles using gamma radiation for selected adsorption of barium and strontium in oilfield wastewater. Arab. J. Chem. 2020, 13, 3762-3774. [CrossRef]

71. Kaveeshwar, A.R.; Kumar, P.S.; Revellame, E.D.; Gang, D.D.; Zappi, M.E.; Subramaniam, R. Adsorption properties and mechanism of barium (II) and strontium (II) removal from fracking wastewater using pecan shell based activated carbon. J. Clean. Prod. 2018, 193, 1-13. [CrossRef] 